\title{
Nuevos datos biográficos de Cayetano y Bruno Pagueras. De Barcelona a La Habana y a La Seu d'Urgell, respectivamente'.
}

\section{New biographical data about Cayetano and Bruno Pagueras. From Barcelona to Havana and La Seu d'Urgell, respectively.}

\section{Joan Benavent Peiró}

Universitat d'Andorra

jbenavent@uda.ad

ORCID iD: https://orcid.org/0000-0002-8856-9335

\section{RESUMEN}

Nuevos datos confirman la relación entre Cayetano Pagueras y Bruno Pagueras como hermanos. A su vez, a partir de los datos de archivo se ha podido reconstruir el circuito profesional que ambos seguirían y que se replicaría en la generación venidera, con los alumnos formados en la catedral de Urgel Francisco Andreví y Ramón Carnicer. Todavía como hipótesis, se plantea que los hermanos Pagueras se formaron con Pedro Antonio Monlleó en Barcelona. Lugar que les permitiría ocupar diferentes cargos de organistas en la Ciudad Condal y acceder a diferentes puestos de maestro de capilla. En el caso de Cayetano, durante un breve período en La Habana y, al menos de manera nominal, en Puebla de los

\footnotetext{
${ }^{1}$ Los resultados del presente estudio forman parte de la tesis doctoral en curso, dirigida por el Dr. Antonio Ezquerro Esteban en la Universitat d'Andorra, que se titula La música en el Bisbat d'Urgell entre 1767-1836 i el seu referent catedralici. Els mestratges de Jaume Balius, Mauricio Espona i Bruno Pagueras (La música en el obispado de Urgel entre 1767-1836 y su referente catedralicio. Los maestrazgos de Jaime Balius, Mauricio Espona y Bruno Pagueras). Las aportaciones aquí presentadas parten del trabajo realizado en diferentes archivos eclesiásticos durante la estancia en el CSIC de Barcelona en el verano de 2017. La investigación de archivo pudo llevarse a cabo gracias a la beca de movilidad para investigadores del Gobierno de Andorra AM058-AND-2017. [Este trabajo se enmarca en los resultados del proyecto coordinado de $\mathrm{I}+\mathrm{D}+\mathrm{i}$ titulado Elpatrimonio musical de la España moderna (siglos XVII-XVIII): recuperación, digitalización, análisis, recepción y estructuras retóricas de los discursos musicales (HAR2017-86039-C2-1-P)]. Por último, aprovecho la ocasión para agradecer a don Benigne Marqués i Sala, canónigo de la catedral de Urgel y archivero del obispado, la ayuda prestada durante el transcurso de la investigación (tanto en la localización de una de las fuentes trabajadas, como en la traducción de los documentos en latín y en la revisión del manuscrito).
} 


\title{
JoAn Benavent Peiró
}

Ángeles. En cambio, en el de su hermano, de los puestos de organista accedería al de maestro de capilla de la catedral de Urgel.

Palabras clave: Bruno Pagueras, Cayetano Pagueras, La Seu d’Urgell, La Habana, Puebla de los Ángeles.

\begin{abstract}
New data confirm the relationship between Cayetano Pagueras and Bruno Pagueras as brothers. In turn, from the archive data it has been possible to reconstruct the professional circuit that both would follow and that would be replicated in the coming generation, with the students trained in the Cathedral of Urgel Francisco Andreví and Ramón Carnicer. Still as a hypothesis, it is suggested that the Pagueras brothers both were formed with Pedro Antonio Monlleó in Barcelona. Place that would allow them to occupy different positions as organists in Barcelona and access to different positions of chapel master. In Cayetano's case, for a brief period in Havana and, at least nominally, in Puebla de los Ángeles. On the other hand, in that of his brother, Bruno would access to chapel master in the Cathedral of Urgel.
\end{abstract}

Key Words: Bruno Pagueras, Cayetano Pagueras, La Seu d’Urgell, Havana, Puebla de los Ángeles.

Benavent Peiró, Joan. (2021). Nuevos datos biográficos de Cayetano y Bruno Pagueras. De Barcelona a La Habana y a La Seu d'Urgell, respectivamente. Cuadernos de Investigación Musical, (13), pp. 25-75.

\section{UNA VISIÓN DE CONJUNTO}

El presente trabajo aporta nuevos datos biográficos inéditos sobre el origen familiar de los hermanos Cayetano Pagueras Portavella (*Barcelona, 31.05.1751; † La Habana?, 19.sc) y Bruno Pagueras Portavella (*Barcelona, ?.01.1753; †La Seu d’Urgell, 27.09.1836) ${ }^{2}$, además de reconstruir el periplo vital de ambos y aportar nueva información a la vida profesional de Cayetano Pagueras.

La investigación aquí presentada aborda la bibliografía localizada sobre Cayetano Pagueras, aportando una confrontación de datos y de publicaciones de mediados del siglo pasado y otras más recientes. Para conocer la biografía y la producción del músico cubano, Alejo Carpentier (1946) y Laureano Fuentes $(1981)^{3}$ daban las primeras noticias sobre el tema,

\footnotetext{
2 Se utilizan las siglas de archivos del RISM. Para más información consúltese http:/ /www.rism.info/sigla.html\#c2487

${ }^{3}$ Las citas relacionadas con el citado trabajo no han podido consultarse directamente de la fuente por no haberla tenido a mano. Es por ello, por lo que las referencias a la misma parten de la bibliografía y de las citas extraídas del resto de publicaciones que lo citan, siendo el caso, el de los estudios de Escudero Suástegui.
} 
Nuevos datos Biográficos de Cayetano y Bruno Pagueras.

De Barcelona a La Habana y a La SeU D’Urgell, Respectivamente

siendo Miriam Escudero quien reunió la información existente hasta el momento y aportó nueva documentación a partir de la catalogación del Archivo de música de la iglesia habanera de la Merced de La Habana. En el estudio, la directora del Gabinete de Patrimonio Musical Esteban Salas, incorporaba materiales inéditos de archivo, a la vez que analizaba y catalogaba las obras del catalán existentes en los fondos musicales de la Merced (Escudero, 1998). De las obras del citado fondo, relataba Escudero, cinco composiciones de Cayetano fueron reformadas por Francisco de Asís Martínez (*?; †1876), quien fuera maestro de capilla de la catedral habanera. Con el tiempo, las publicaciones sobre la biografía de Cayetano se han visto ampliadas por la investigadora y todo el equipo del citado Gabinete con nuevos datos de archivo y con grabaciones de audio y de video (Escudero, 2013a, 2013b, 2015, 2016).

Además de las publicaciones de Miriam Escudero ${ }^{4}$, recientes trabajos han aportado nueva información de interés. En concreto, Margarita Pearce, en su trabajo sobre la actividad musical en los espacios religiosos de La Habana, aportaba datos sobre la recepción de la obra de Cayetano partiendo de la documentación localizada de Francisco de Asís Martínez. Según la investigadora, a la llegada de Asís en 1857 a la catedral de la Habana, la obra de Pagueras todavía se interpretaba en la misma sede catedralicia y así continuó a partir de los arreglos antes comentados (Pearce, 2016). Además, Pearce anota la existencia de un inventario de los papeles de música de la catedral de La Habana de 1872, que ya había anotado con anterioridad Escudero (1998, p. 42), que muestra la presencia de obras del catalán en la catedral habanera en la segunda mitad del siglo diecinueve. A su vez, Carpentier anunciaba, siendo una cita repetida en la bibliografía sobre el tema, que el archivo habanero había llegado a tener por aquellos años 623 obras de diferentes compositores, siendo algunas de Pagueras, y que, al parecer, se habían perdido en su totalidad (Carpentier, 1946, p. 120).

Otra de las investigaciones que han incluído nuevos datos de archivo ha sido el trabajo de Miriam Dalila Franco. Abordando la figura de Manuel de Arenzana (*Soria, 24.03.1750; †Puebla de los Ángeles, 21.08.1821), la investigadora estudia la presencia de Cayetano en la catedral de Puebla de los Ángeles incorporando documentación de archivo. Se trata de las oposiciones al cargo de maestro de capilla que se llevaron a cabo en 1778 y de la oposición que al parecer se realizó en 1791, y que habían sido ya trabajadas por Escudero a partir de la presencia de obras de Pagueras en la catedral angelopolitana (Franco, 2019). Dicha información también había sido anotada por Montserrat Galí (2017), siendo el estudio de Miriam Dalila el que transcribe documentación, hasta el momento, inédita sobre el tema.

Junto con los trabajos citados, otras publicaciones, que a lo largo del estudio se verán, han ido reuniendo y anotando la información antes comentada, aportando, en el caso de Robert Stevenson (1978) y de Stanford (2002), datos de interés sobre la obra de Cayetano

\footnotetext{
${ }^{4}$ Hasta la aparición de los estudios de Escudero las referencias biográficas sobre Cayetano se han ido repitiendo a partir de las noticias que Carpentier aportó en su momento y que Stevenson, ya unos años después, amplió (Carpentier, 1946, pp. 135-141; Stevenson, 1978, p. 178; Bimberg, 1993, p. 2838; Escudero, 1998; Sáenz, 2001, p. 353; Rodríguez, 2004, p. 381; Escudero, 2013a, 2013b; Lorenzino, 2013, p. 107; Bermúdez, 2014; Álvarez, 2014, p. 354; Escudero, 2015, 2016; Pearce, 2016).
} 


\section{JoAN BENAVENT PEIRÓ}

Pagueras. A su vez, Carmen María Sáenz realizaba la entrada bibliográfica relativa al catalán emigrado a Cuba en el Diccionario de la Música Española e Hispanoamericana (Sáenz, 2001).

Después de la revisión bibliográfica relacionada con Cayetano, la investigación aquí presentada trata, aunque de manera muy somera, la bibliografía existente sobre la biografía y la obra del hermano Bruno Pagueras, siendo, tan solo, un mero apunte, dado que se espera poder ofrecer nueva información y una biografía crítica del citado autor, a partir de los resultados de la tesis en curso antes mencionada ${ }^{5}$. Aun así, el estudio revisa la visión con la que la historiografía ha tratado la figura del autor urgelense, empezando con las referencias que Mariano Soriano-Fuertes (1855) y Baltasar Saldoni (1881) hacían del mismo, siendo los primeros que lo citan. En el caso de Bruno, serían los trabajos llevados a cabo por Jordi Roig, transcribiendo materiales del Archivo Capitular de La Seu d'Urgell, los que aportaron las primeras referencias del compositor en su contexto (Roig, 2004). Diferentes han sido las publicaciones que han reunido nueva información sobre el músico urgelitano, siendo la entrada bibliográfica de Josep Maria Llorens la que daría una visión de conjunto del compositor, a la vez que clarificaba la diferencia de apellidos con la que se encuentra el músico en la bibliografía, siendo Pagueras su apellido, y encontrándolo como Paqueras en diferentes publicaciones (Llorens, 2001, p. 353). Otros son los trabajos que han ampliado la figura del compositor con nueva información de archivo sobre su actividad musical (Benavent, 2014, 2018, 2019, 2020). Aun así, el trabajo de Gloria Ballús y de Antonio Ezquerro (2016, 2019a, 2019b) es el que aborda el tema de la influencia del compositor en su propio centro de trabajo a partir de la actividad pedagógica llevada a cabo con alumnos como Francisco Andreví (*Sanaüja, Lleida, 1786; †Barcelona, 1853) y Ramón Carnicer (*Tàrrega, Lleida, 24.10.1789; †Madrid, 17.03.1855).

A continuación, el artículo aporta información inédita sobre la ascendencia familiar de ambos músicos, a partir de los documentos conservados en diferentes archivos. De todos ellos, los libros de esponsales han aportado su ascendencia familiar, sirviendo de base para contrastar la información extraída en: los libros de bautismo, la proclamación a las órdenes eclesiásticas de Bruno, una demanda matrimonial de Cayetano y, para finalizar, el último testamento de Bruno Pagueras. Del conjunto de la información extraída, junto con el resto de los aspectos biográficos han podido reconstruirse los periplos laborales de ambos músicos y fundamentar, así, la hipótesis planteada del circuito musical de ambos Pagueras. Dicha información se incluye en un anexo al final del estudio, tanto en transcripción diplomática, como normalizada, con un total de 10 documentos inéditos de archivo.

Además, el presente estudio plantea la trazabilidad que puede reconstruirse a partir de los pasos y de los cargos, así como de los puestos que ostentaron, partiendo de una supuesta formación musical con el maestro de la capilla de Santa María del Mar en Barcelona bajo la tutela de Pedro Antonio Monlleó ${ }^{6}$ (*Barcelona, 1720c; †Ibid, 14.07.1792). Así, entre los

\footnotetext{
${ }^{5}$ La música en el Bisbat d’Urgell... op. cit.

${ }^{6}$ De su producción musical destaca el género del oratorio, pero del que tan solo se conservan algunos textos, sin tener todavía hoy noticia de sus partituras, que desaparecieron con la quema del archivo de Santa María del Mar de Barcelona, en 1936. Se ha localizado su participación como salmista de la catedral de Barcelona, en 1753, cargo con el que pasaría a ejercer, con idénticas funciones, en la iglesia de Santa María del Mar. Finalmente, en el año 1759 accedería al cargo de maestro de capilla de dicha iglesia, puesto que ostentaría hasta su
} 
citados pasos, ambos ejercieron los cargos de organista de diferentes conventos barceloneses, como era práctica habitual en la época, y que les permitiría promocionarse, a la vez que perfeccionar el oficio de músico que ambos empezaban a ejercer.

Por aquellos años, la Ciudad Condal contaba con una cierta cantidad de conventos intramuros de diferentes órdenes religiosas que, de manera paulatina, fueron desapareciendo durante los primeros años del período liberal español. A la postre, la reforma urbanística del denominado «Plan Cerdá» de 1860 acabaría con la demolición de muchos de los edificios que quedaban, y que serviría para remodelar la trama urbana con nuevas calles y plazas. Dicha reforma supuso el traslado de algunos edificios conventuales al actual ensanche urbanístico. Por poner algunos ejemplos, directamente relacionados con La Seu d'Urgell, los conventos de la Inmaculada Concepción de religiosas carmelitas descalzas de Santa Teresa, el de Santa María Magdalena de madres agustinas, o el femenino de Junqueras de la Orden de Santiago, fueron centros en los cuales el músico Francisco Andreví, alumno de Bruno Pagueras en la catedral de Urgel, ejerció, a inicios del siglo diecinueve, las funciones de organista.

Dicho puesto, el de organista conventual, ofrecía a los músicos una oportunidad laboral que podían compaginar con la asistencia a la bulliciosa actividad musical barcelonesa del momento (Ballús \& Ezquerro, 2016, pp. 68-76, 2019a, 2019b). Es por ello, por lo que tanto maestro como alumnos, es decir tanto Bruno Pagueras como Francisco Andreví y Ramón Carnicer — y también Cayetano en sus primeros años - siguieron el antedicho circuito de promoción profesional entre sus capillas de formación musical y sus futuros cargos de organistas.

fallecimiento. Según palabras de Baltasar Saldoni, Monlleó “fue muy reputado, y gozó en Cataluña, pero aún más en Barcelona, de envidiable fama como compositor” (1880, p. 40). En cuanto a su producción, además de sus oratorios, se conservan composiciones dedicadas en su integridad a la música religiosa, encontrándose sus obras en los archivos de Manresa, Teruel, Segorbe, Barcelona, Cervera, La Seu d’Urgell, Vilanova i la Geltrú, Vilafranca del Penedès y Olot (Baldelló, 1962; Llorens, 2000, p. 696; Rife, 2001; Ballús, 2004, pp. 82-91 y 2009, pp. 263, 273). 


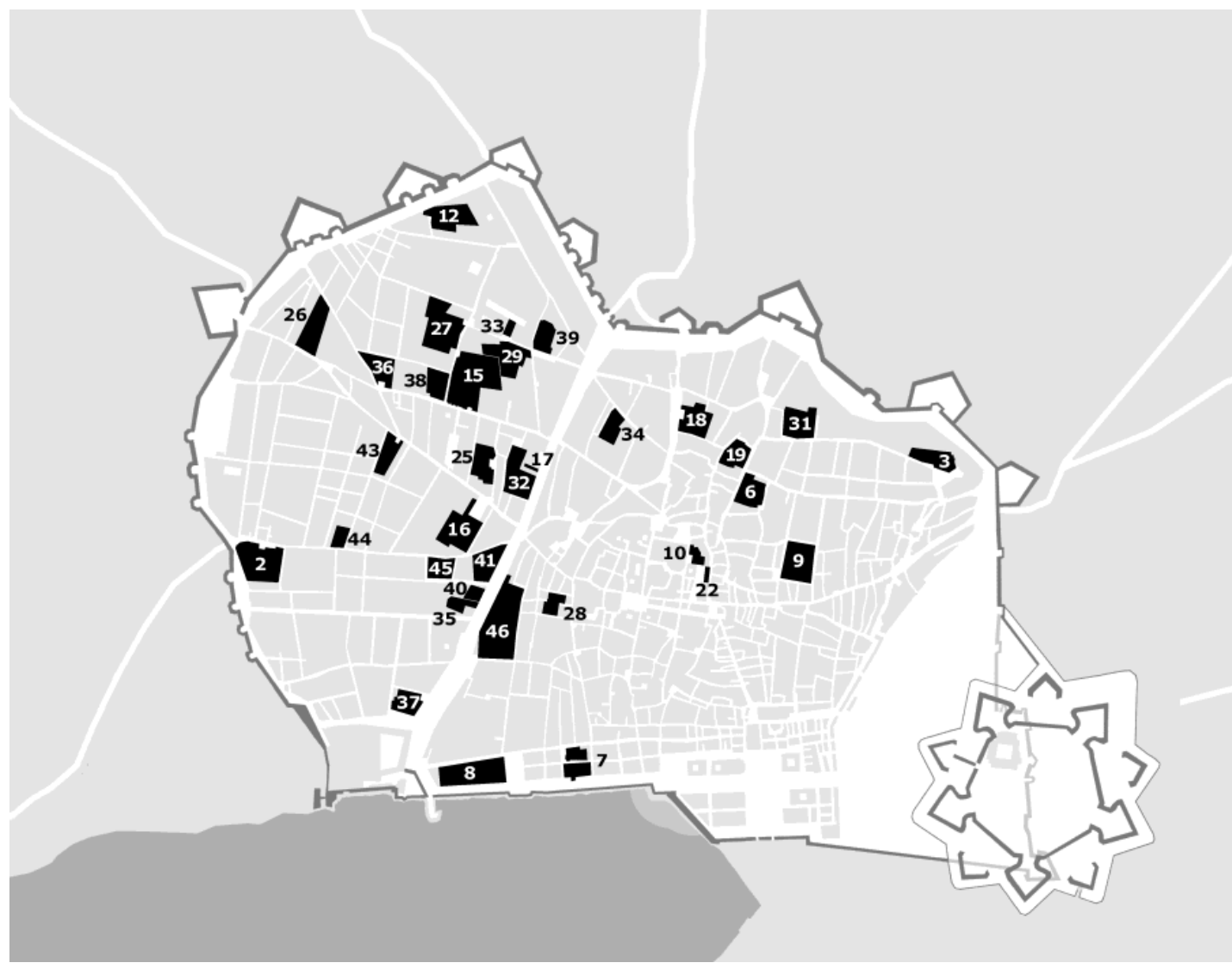

Fig. 1: Monasterios y conventos de Barcelona en el año $1835^{7}$.

(Información extraída del web: https://monestirs.cat/monst/bcn/bcn22.htm [fecha de consulta: 01.03.2020])

\section{Cayetano Pagueras Portayella}

De Cayetano Pagueras, como viene dicho, Miriam Escudero ha estudiado y publicado la mayor parte de la obra localizada del compositor (1998, 2013a, 2013b, 2015, 2016) ${ }^{8}$. Escasas son las referencias de su biografía antes de su llegada a Cuba, conociendo, tan solo,

\footnotetext{
${ }^{7}$ A lo largo del siglo XVIII fueron aumentando los monasterios y conventos dentro del recinto amurallado de la Ciudad Condal. En el año 1835 Barcelona contaba con los centros que a continuación se citan: 2. Sant Pau del Camp; 3. Sant Pere de les Puelles; 6. Sant Joan de Jerusalem; 7. La Mercè; 8. Sant Francesc; 9. Santa Caterina; 10. Santa Clara; 12. Valldonzella; 15. El Carme; 16. Sant Agustí; 17. Natzaret; 18. Montsió; 19. Santa Maria Magdalena; 22. Capella Reial; 25. Santa Maria de Jerusalem; 26. Sant Maties (también conocido como Santa Margarida o de Les Jerònimes); 27. Els Àngels; 28. La Trinitat; 29. Santa Elisabet; 31. Sant Francesc de Paula; 32. Sant Josep; 33. Sant Guillem d'Aquitània; 34. Santa Teresa; 35. Sant Àngel; 36. Santa Margarida la Reial; 37. Santa Mònica; 38. Jesús Maria; 39. Bonsuccés; 40. Sant Bonaventura; 41. Bonanova; 43. La Encarnación; 44. Sant Vicent i Sant Ramon; 45. Agustines Penedides; 46. Santa Madrona [la información se ha extraído de una página web interactiva que muestra la evolución de los cenobios, y es por ello por lo que la numeración de los centros no es correlativa, según como aparece en el mapa interactivo]. De todos los conventos y monasterios citados tan solo conciernen al artículo los reiterados de la Valdonzella y Las Jerónimas, de los cuáles no se conservan documentos del período estudiado y tampoco partituras, según se nos ha detallado en el Archivo del obispado de Barcelona.

${ }^{8}$ Unos años después de la publicación de Escudero (1998) del catálogo de la iglesia habanera de La Merced aparecía, en el Diccionario de la música..., op cit., una entrada enciclopédica dedicada al compositor que resumía los datos enunciados por Escudero (Sáenz, 2001, p. 353).
} 
Nuevos datos biográficos de Cayetano y Bruno Pagueras.

De Barcelona a La Habana y a La SEU D'Urgell, RESPECTIVAMENTE

su faceta como organista del convento de las Jerónimas de la ciudad de Barcelona. Dato que se desprende del memorial realizado para unas polémicas oposiciones de organista en la parroquial de Sant Pere i Sant Pau de la localidad de Canet de Mar (Barcelona) ${ }^{9}$, en fecha de 30 de julio de 1774.

En dicha ocasión, Pagueras participaba en el tribunal junto a Lluís Parera ${ }^{10}$, ambos como oyentes, y con Martí Pibernat $(* 1737$; †1783) y Francesc Serra (†1801), como especialistas en la interpretación del órgano (Salicrú, 1995, pp. 39-40) ${ }^{11}$. De la lectura de la

\footnotetext{
${ }^{9}$ La parroquia de Sant Pere i Sant Pau de Canet cuenta hoy con un archivo histórico-musical con 2119 obras, con presencia de autores hispánicos de los siglos XVII y XVIII (Mas, 2004; Bonastre, Gregori \& Guinart, 2009; Gregori, 2009; Mas \& Saiz, 2009; Gregori, 2012; Alcalde, 2017; Gregori, 2020). En dicho archivo se conserva una misa de Bruno Pagueras, con signatura 7/778 e inventariada en https://ifmuc.uab.cat/record/1398 [fecha de consulta: 15.07.2020] (Bonastre, Gregori \& Guinart, 2009, p. 379), de la que existe otra copia en el archivo capitular de Urgel (con signatura provisional $\boldsymbol{E}$-SUe, UI.1658.023.1. Este último documento se encuentra inmerso en el proceso de catalogación en curso de los fondos del Archivo Capitular de Urgel, fruto del trabajo llevado a cabo para la tesis La música.... op. cit.).

${ }^{10}$ Lluís Parera (*Barcelona, 1703; †?, 1783) fue organista de la parroquia de Sant Miguel del Puerto de Barcelona (parroquia que sería años más tarde asimilada a Nuestra Señora de la Merced) y en 1734 pasó a ejercer el mismo cargo en la iglesia de Santa María de Mataró, sin haber realizado oposiciones, hasta el año 1778 (Cabot \& Gregori, 2010, p. XXXVI).

${ }^{11}$ El 9 de julio de 1774 fallecía Llorenç Ferrer Clausell, quien hasta la fecha había sido el organista de la parroquia de Canet de Mar. El traspaso dejaba vacante el puesto de la organistía y se iniciaba un proceso de selección para el cargo. El 30 de julio se iniciaban unos exámenes, que se verían inmersos en cierta polémica. Como examinadores actuaron los organistas Martí Pibernat de la parroquia de Sant Martí d'Arenys de Munt (Barcelona) y Francesc Serra, de Santa Maria d'Arenys de Mar (Barcelona). A su vez, como oyentes, participaron, al menos a priori, los organistas Lluís Parera, de Santa Maria de Mataró (Barcelona) y Cayetano Pagueras, por aquel entonces licenciado (a quien se le cita "Gaetano" — probablemente en atención a la entonces imperante "moda" operística italiana, y seguramente también por la oscilación del nombre en lengua catalana, como "Caietà" o "Gaietà"-), como se ha visto, procedente del convento de monjas Jerónimas de Barcelona. Al examen contendían Joan Oller Matas, clérigo, y Josep Casalins Castanyer, licenciado, ambos oriundos de Canet de Mar (Alcalde, 2017, p. 8). A tenor del certificado emitido por el notario Josep Llobet, los dos aspirantes fueron puestos a prueba con diferentes preguntas sobre música, la interpretación del órgano y otros aspectos. De resultas del examen, Josep Casalins ganó la plaza habiéndose mostrado más hábil, tanto en la entonación del canto llano, en el acompañamiento (se sobreentiende que al órgano), como, también, en la salmodia. El 17 de julio, continua Alcalde Vilà, la comunidad parroquial emitió un acta de admisión de Casalins como organista de la parroquia, pero puede suponerse un error de transcripción [repetido en (Bonastre, Gregori \& Guinart, 2009, pp. XXVIII-XXIX) y en (Gregori, 2012, pp. 69-70)], puesto que todavía no se había realizado el examen [o, acaso, ¿sería el motivo del polémico examen?]. En cualquier caso, en el documento de admisión al cargo de organista, al ganador de la plaza se le asignaban las tareas de tocar el órgano y de acompañar a la capilla de música. Pero, a su vez, se le otorgaban otras tareas propias del cargo de párroco de la iglesia (Alcalde, 2017, p. 8). Así pues, la confrontación de la información consultada pone en entredicho la fiabilidad de la oposición. Del examen se redactó un certificado, firmado por ambos organistas examinadores, que detallaba las circunstancias de la prueba y los resultados de esta. En la transcripción del documento de Salicrú, se lee: “segons nostre Perícia y pràctica en lo offici de orga, nosaltres declaram que los dits exàmens no foren exàmens, sinó sombra de exàmens, per faltar las degudas circunstàncias principals en semblants exàmens y ab tot lo dit, Joan Oller, clerga, donà major satisfació, y dublicada, que no donà lo dit Joseph Casalins, Licenciado" (traduzco: "según nuestra pericia y práctica en el oficio de órgano, declaramos que los dichos exámenes no fueron tales, sino sombra de exámenes, por faltar las debidas circunstancias principales en semejantes exámenes; y con todo lo dicho, Joan Oller, clérigo, dio mayor satisfacción, y duplicada, cosa que no dio el citado Joseph Casalins, licenciado"). Al parecer, el resultado del examen no debió agradar a alguno de los no agraciados puesto que el 4 del mes siguiente, Lluís Parera, quien había actuado en la oposición como oyente juntamente con Pagueras, firmaba una declaración jurada ante notario, donde declaraba no haber escuchado las respuestas de los aspirantes. En el memorial, Parera clarificaba haber oído a Joan Oller (no queda claro qué hubiese podido haber escuchado, si las respuestas orales a determinadas cuestiones que se le plantearon o si el acompañamiento al órgano), y a su vez decía que dicho aspirante no era hábil para el canto llano, pero que no disponía de más información. Fuera como fuese, al parecer, las pruebas no estuvieron exentas de polémica. De los datos de archivo se desprende que el puesto de organista continuó
} 


\title{
JoAn Benavent Peiró
}

información conservada del examen se desprende la participación de Pagueras como un mero oyente en el proceso sin haber tenido, posiblemente, ocasión de interferir en los resultados de las pruebas. Por este motivo, podría plantearse su ausencia en la declaración que su compañero en el examen, Lluís Parera, otro mero oyente, había emitido ante notario de estas. Tal hecho induce a pensar que el citado Pagueras podría no haber querido verse involucrado en un asunto tal como es una impugnación, que al parecer se estaba llevando a cabo, para evitar así una implicación como cómplice "por omisión” del veredicto del examen.

Siguiendo con sus datos biográficos, se había anotado que a los 14 años ya era organista en Barcelona (Carpentier, 1941, p. 110; Sáenz, 2001, p. 353). La cuestión es que a tenor de la información contrastada entre la mencionada oposición de Canet del Mar en 1774 y los datos aportados inicialmente por Alejo, Cayetano podría haber ejercido el cargo de organista en Barcelona en 1765 y con 23 años, según lo visto, haber ejercido el puesto de manera "profesional", sino con anterioridad. Por tanto, la temprana edad a la que Carpentier alude sería la época en la que Pagueras podría encargarse, ocasionalmente y como diría Louis Jambou, de la organistía, en condición de suplente, cubriendo las ausencias del organista titular de su capilla musical de origen, como era más o menos frecuente entre los estudiantes avanzados en la época. Por otra parte, tales "prácticas" les servirían a los estudiantes aventajados, y en el caso aquí tratado a Cayetano Pagueras, para poder promocionarse a su futuro cargo laboral en el convento de las Jerónimas de Barcelona.

Dentro del estudio biográfico del compositor hay una alusión de Laureano Fuentes que aporta cierta confusión. Véase la cita:

\begin{abstract}
Llegaron a ser notables en la ejecución de la misa [refiriéndose a la música en la catedral de Santiago de Cuba] el maestro español Pacheco, y en la preciosa partitura de igual género, del [sic] maestro Cayetano Pagueras (de Barcelona) que por los 12 o 14 años residió aquí [en Santiago de Cuba] por poco tiempo; marchándose luego a la Habana como organista de aquella catedral hasta 1821 (Escudero, 1998, pp. 44-45; Fuentes, 1981, p. 125).
\end{abstract}

La mencionada confusión aparece con la referencia que Laureano hacía de la presencia de Cayetano en Santiago de Cuba, además de referirse a los 12 o 14 años, puesto que publicaciones recientes sobre el tema no lo han tratado. En el caso en cuestión, se plantea que previa a su estancia habanera, Cayetano permanecería en la ciudad santiaguera, aunque se desconoce la duración de la misma. Caso aparte es la mención de los 12 o 14 años a que se refiere, que tampoco aclara las cosas. Tal cita, la santiagueña, merecería hoy una revisión pormenorizada, puesto que diferentes publicaciones relacionadas con la actividad musical en la catedral de Santiago de Cuba en el período tratado no han vuelto a mencionarlo. En dichos estudios se abordaba la biografía de Esteban Salas durante sus años habaneros y la biografía

ejerciéndolo Josep Casalins, pese a las diferencias de opiniones del tribunal, cargo en el que todavía se le localiza, en diferentes funciones en 1792 y 1795, además de continuar como organista, hasta su muerte en 1814 (Alcalde, 2017, p. 8). En cualquier caso, y volviendo a la biografía de Cayetano Pagueras, la documentación generada a raíz del examen sitúa al músico emigrado a Cuba en suelo catalán, todavía, el 30 de julio de 1774. 
Nuevos datos biográficos de Cayetano y Bruno Pagueras.

DE BARCElona A LA HABANA Y A LA SEU D'URGELL, RESPECTIVAMENTE

y el acceso al cargo de maestro de capilla de Juan Paris en Santiago de Cuba, sin hacer, ninguna de ellas, mención alguna a la figura de Cayetano (Hernández, 1964; Escudero, 2012; Fallarero, 2012).

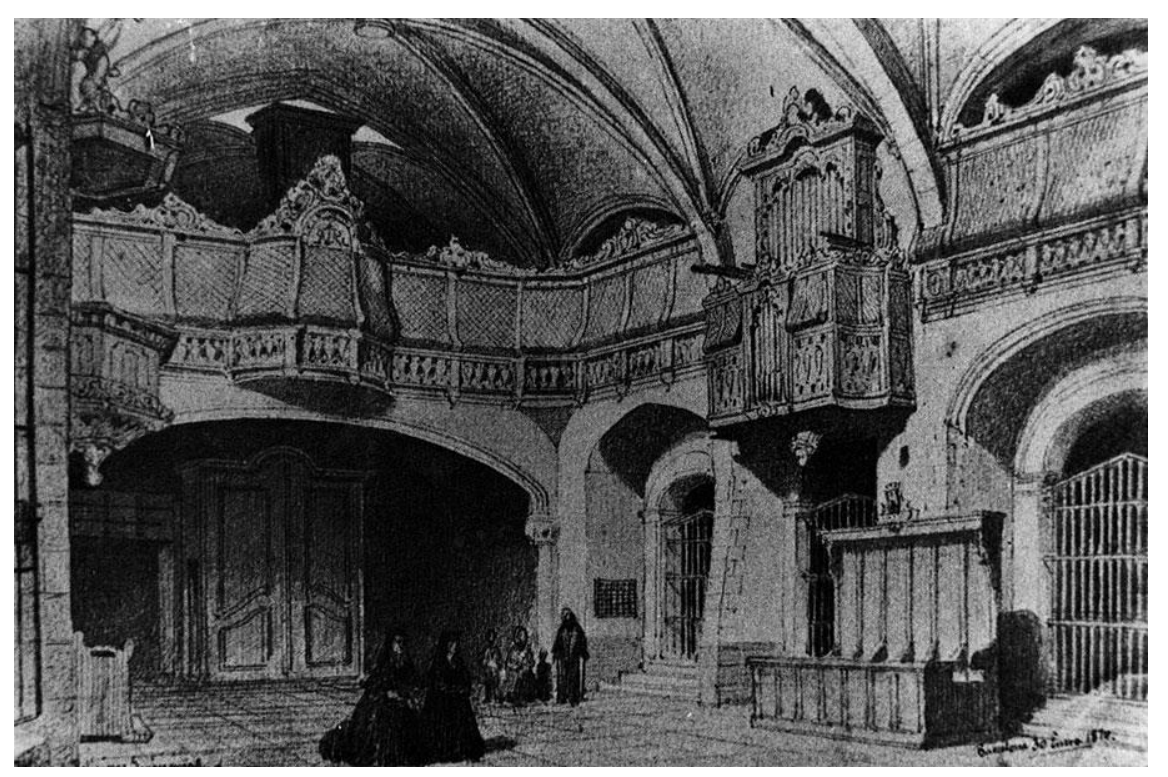

Fig. 2: Interior de la iglesia de las Jerónimas de Barcelona, donde ejerció el cargo de organista Cayetano Pagueras, de 1870 y hoy destruida.

(Històries i llegendes de Barcelona [Amades, 1984])

Volviendo a sus años de ejercicio barceloneses, gracias a un documento que se verá más adelante se le ubica de nuevo en Barcelona el 28 de enero de 1775, información que estrecha el período en que pudo haber emprendido su viaje a ultramar.

Después de la citada fecha, hay que esperar tres años para situarlo, ahora ya, en suelo cubano y manteniendo una cierta actividad con el cabildo de la catedral de Puebla de los Ángeles en el virreinato de la Nueva España, hoy México (Escudero, 2013a, pp. 14, 22, 2013b, s.p.).

En concreto, gracias a una carta que Cayetano enviaba al cabildo de Puebla, el 8 de diciembre de 1778 se concreta, por primera vez, su estancia en la isla, pero, además, el documento permite establecer el punto de partida para las futuras relaciones entre el músico y la entidad angelopolitana. En la carta, el músico anunciaba que ya en el mes de mayo de 1778 había escrito al cabildo para ofrecerse a los puestos de organista y de maestro de capilla, de los que tenía constancia de la vacante, al menos, de uno de ellos. A su vez, Cayetano escribiría la carta, en un momento en que José Joaquín Lazo de Valero $(† 1778)^{12}$ —quien

\footnotetext{
12 Sobre el examen de oposición a la catedral de Puebla de los Ángeles del maestro José Joaquín Lazo Valero del 4 de febrero de 1749 véase el trabajo de Patricia Díaz (2007). Dicho estudio reúne una serie de obras que estuvieron en poder del compositor y que ofrece el interés del compositor hacía autores como Pedro Rabasa, Nicolás Ximénez, José de Torres y Francisco Atienza, además de incluir en el trabajo el examen de oposición
} 


\section{JoAn Benavent Peiró}

había sido el maestro de capilla hasta entonces - acababa de fallecer, teniendo así el cabildo una plaza vacante para el cargo. Dicha carta, corroboraba las afirmaciones planteadas con anterioridad en diferentes publicaciones que anotaban la relación entre el músico y el cabildo angelopolitano a partir de las partituras conservadas de Cayetano en México (Escudero, 2913a, 2013b).

En este mismo sentido, Galí Boadella (2017, p. 173) anotaba que desde el momento de la renuncia al cargo de maestro de capilla de la catedral de Puebla del maestro José Joaquín Lazo de Valero en 1776, la catedral contaba con un período de varios interinatos. Sería entonces, con ocasión de la renuncia del cargo de maestro de capilla de Lazo de Valero, el momento en que el cabildo iniciaría los trámites para convocar unas oposiciones, enviando los edictos de la convocatoria a los principales centros del momento, al menos cercanos, como venía siendo preceptivo en la época. En este sentido, John Koegel (2000, p. 824) anota que, con motivo de la dicha renuncia de Valero, se enviaban edictos a la catedral de México. La citada carta, trabajada por Escudero $(2015)^{13}$ anotaba lo siguiente:

En mayo proximo pasado escriví a Vuestra Señoría Ylustrísima, otra de igual asumpto ha esta de la que caresco de noticia siendome mui sencible su extravio, porque en ella manifestava mas por extenso, las sircunstancias que en mi caben pertenecientes al desempeño de las Plazas de organista he Maestro de Capilla que por entonces me digieron se hallava vacante una de las dos.

En el día se me ha dado por noticia cierta ha fallecido el Maestro por cuyo motivo repito mi instancia a fin de que si la maestría se da por Oposiciones, se digne Vuestra Señoría Ylustrísima contestarme ha esta concediéndome tiempo oportuno para poderme presentar ha ellas, pues aunque mi suerte no fuera benemérita quedare con seguridad haver manifestado a Vuestra Señoría Ylustrísima mi buen deceo en quererme constituir por uno de sus sirvientes, siendome merito mi trabajo para lo futuro en lo que se me pueda atender de la Capilla. (Escudero, 2015, p. 5).

En este sentido, Franco Gutiérrez anotaba:

sabemos que la relación de Pagueras con la catedral poblana se había establecido desde 1778, cuando este había comenzado a enviar obras con el afán de ser contemplado como sucesor de José Lazo Valero (Franco, 2019, p. 63).

al cargo, donde el aspirante mostró un claro dominio del canto de órgano en estilo moderno. A su vez, Boadella anota diferentes composiciones del compositor que pudieron haber formado parte de las exequias de Puebla durante el siglo XVIII, anotando once primeros registros de un inventario de 1778 al compositor Lazo y Valero (Galí, 2007, p. 56).

${ }^{13}$ Véase la transcripción completa en el estudio de Escudero op. cit. 


\section{Nuevos datos biográficos de CAYETANO Y BRUno Pagueras. \\ DE BARCELONA A LA HABANA Y A LA SEU D’URGELL, RESPECTIVAMENTE}

Después de la citada fecha habrá que esperar hasta 1790 para volver a tener noticias de la relación entre Cayetano y Puebla. Aun así, y siguiendo con la idea anotada por Galí de los interinatos poblanos, el cabildo andaría buscando un aspirante válido para el cargo, teniendo que lidiar tales asuntos entre los músicos de dentro y fuera de la capilla.

En este punto, tanto Escudero, partiendo de las partituras de Pagueras conservadas en Puebla, como Franco Gutiérrez, incorporando nuevos materiales de estudio, han corroborado las aspiraciones del catalán para optar a la capellanía de la catedral pueblana, pero existe un documento, no contemplado hasta la fecha, que aporta nueva información alrededor de las oposiciones de 1791. A su vez, el documento en cuestión replantea el relato historiográfico presentado hasta el momento, puesto que, como se verá, Cayetano fue maestro de capilla de la catedral de Puebla, aunque, al parecer, sin llegar a ejercer dicho puesto, siendo el cargo, tan solo, nominativo. Veámoslo, pero antes convendría revisar algunos detalles previos.

Con relación a los contactos entre el cabildo angelopolitano y Cayetano Pagueras, anotaba Galí Boadella una relación previa a 1790 entre Salvador Biempica y Sotomayor ${ }^{14}$ (*1727; †1802), quien llegaría a ser obispo de Puebla a partir de 1790. Según Galí, dicha relación vendría de la propia catedral de La Habana (Galí, 2017, pp. 173-174). Al parecer, tal aspecto parece poco factible, dado que dicho obispo, en el supuesto de haber estado en La Habana, no habría coincidido con Cayetano, puesto que el segundo llegaría a la isla, como se anotaba anteriormente, en fecha posterior a 1775. Para dicho año, el futuro obispo angelopolitano vendría ocupando el cargo de chantre $^{15}$ en la catedral de Valladolid, en la provincia de Michoacán, hoy "Morelia"16.

En cualquier caso, relata Franco Gutiérrez $\left(2019\right.$, pp. 63, 65, 128) ${ }^{17}$, el obispo de Puebla había dado instrucciones de quedarse a la espera de una respuesta de Cayetano para la obtención del cargo de maestro de capilla.

Certifico qe en el libro N. 47 de cabildos está asentado / un tenido en / diez de diciembre de mil setecientos y noventa y en el / una acta capitular del tenor siguiente. [Margen izquierdo:] N. 3. el s ${ }^{\text {or }}$ Conde, comisionado con el Sor (¿?) [sic] Franco / de la Vega para arreglo de la capilla de / coro, hizo presente que ntro. / $\mathrm{Ym}^{\circ}$ Prelado ha / bia

\footnotetext{
${ }^{14}$ Sobre su biografía y sus acciones como obispo véanse la Oración fúnebre del ilustrísimo señor D. Salvador Biempica y Sotomayor [...] pronunciada [...] el día 16 de diciembre de 1802 (Pérez, 1804), el estudio sobre los aspectos políticos y jurídicos del prelado durante su estancia en Puebla (Salazar, 2005) y el contexto que Franco Gutiérrez (2019) realiza para presentar la figura de Manuel Arenzana.

15 Tales datos parten del artículo realizado por Juan Pablo Salazar (2005) sobre los aspectos políticos y jurídicos del obispo de Puebla Biempica.

${ }^{16}$ Es decir, que la antigua ciudad de Valladolid de Michoacán pasaría a llamarse, tras los acontecimientos revolucionarios, y en honor al general Morelos, como "Morelia", nombre que ostenta en la actualidad, aunque todavía, esporádicamente, pueda mencionarse hoy día eventualmente su nombre antiguo de Valladolid.

17 Además de las transcripciones realizadas por Franco Gutiérrez (2019), una parte de la documentación transcrita en la citada publicación puede consultarse en la base de datos realizada por la Universidad Nacional Autónoma de México: Actas de cabildo. Base de datos de actas de cabildo y otros ramos. Seminario de música en la Nueva España y el México independiente. Instituto de investigaciones estéticas. Disponible en: http://www.musicat.unam.mx/actas/actas.php [fecha de consulta: 06.08.2020].
} 


\section{JoAn Benavent Peiró}

determinado no tomar resolucion / alguna hasta ver si venía de la Habana / un maestro de Capilla, qe tenia hablado / a tal efecto, y oído por por los SS Dixeron, / qe se hiciera en todo como pensaba su sña Ylma. (Franco, 2019, p. 128).

De la transcripción anterior se desprende que el cabildo designó una comisión para gestionar la capilla, contado, entre otros, con los señores Conde y Francisco de la Vega. Pero, a su vez, el documento indica que el obispo — por aquel entonces ya Salvador Biempica, y habiendo hecho la toma de posesión de la prelatura el 17 de agosto de 1790—, había determinado no tomar ninguna resolución vinculada con la capilla de música, hasta que llegase una respuesta de un maestro de capilla que venía de La Habana. Así pues, podría plantearse que, desde la propia capilla, se intentase cubrir el puesto vacante, o incluso de que cualquier otra aspirante pudiese haber motivado la redacción del citado memorial, previas gestiones, y habiendo conseguido conmover al obispo para que se pronunciase. Cabe recordar que, dando por válida la afirmación de Boadella antes vista, el cabildo estaba inmerso en un proceso de continuos interinatos, desde la renuncia al cargo del maestro José Joaquín Lazo de Valero en 1776. Ante tales hechos, y posiblemente ante el clima en que se encontraría la comisionada capilla musical, el obispo se vería obligado a interceder y ejercer su voluntad mandando esperar a sus comisionados, antes de seguir con una supuesta resolución al conflicto abierto.

Es por todo lo anterior por lo que, siguiendo con la visión historiográfica aceptada hasta ahora, el siguiente examen de oposición nos llevaría a 1791, estando en un período de interinidades que concluiría con la designación de Manuel Arenzana en el cargo de maestro de capilla, como más adelante se verá que finalmente ocurrió, aunque con matices.

Aun así, y para no acelerar el relato, merecería la pena plantear otra solución al problema basada en otro documento que ni Franco Gutiérrez ni tampoco Escudero en sus investigaciones previas habían contemplado. Tal documento plantea otro escenario: ¿podría suponerse que el cabildo ya hubiese otorgado el puesto a Cayetano? ¿Sería factible plantear dicha posibilidad? En tal caso, y al no llegar una respuesta desde La Habana, tanto la capilla como sus integrantes podrían haber empezado a presionar al cabildo para tomar una pronta resolución en el asunto. Gracias al nuevo documento antes mencionado se planteará la "otra" resolución del asunto, diferente a la aceptada hasta la fecha.

Según la transcripción de la carta anterior, en la que el obispo mandaba esperar a sus comisionados, podría considerarse que el cabildo de Puebla, en fecha de 10 de diciembre de 1790, ya podría haber asignado el cargo de maestro de capilla a Cayetano Pagueras. O, al menos, que ya se estuviese planteando asignarle el puesto a Cayetano, siendo el motivo por el cual el obispo mandaría tener a la espera a sus comisionados, mientras le llegaba al cabildo una respuesta de la confirmación de Pagueras en el cargo.

Dicha hipótesis, vendría refrendada por el hecho de que unos meses después, concretamente el 24 de marzo de 1791, el cabildo de la catedral de Puebla acordaba enviar a Cayetano Pagueras trescientos pesos en adelanto, de los mil que tendría en el sueldo, para que pudiese presentarse al puesto de maestro de capilla. ¿Acaso el hecho de pagarle un 
Nuevos datos biográficos de CAYETANo y BRUNo Pagueras. DE BARCElona A LA HABANA Y A LA SEU D'URGELL, RESPECTIVAMENTE

adelanto de su propio sueldo no le confería per se el cargo de maestro de capilla de la catedral? $¿ \mathrm{O}$, en cambio, se le abonaba una cantidad simplemente de antemano? La conjetura ahora vista, planteada a partir de la "nueva" información, cobra más sentido, todavía, a partir de la transcripción siguiente que recalca que el maestro para la plaza ya era Cayetano Pagueras y que, además, estaría ya en Veracruz, al menos, en la citada fecha del 24 de marzo. La nota dice así:

En la ciudad de la Puebla de los Ángeles a veinticuatro de marzo, el señor deán juntó pelicano compuesto de varios señores, y el señor doctor Conde, comisionado para el arreglo de la capilla del coro, hizo presente que el maestro para ella, Pagueras, de acuerdo con su señoría ilustrísima, nuestro dignísimo prelado, se había llamado de la Habana, ofreciéndole mil pesos de sueldo, adelantándole a cuenta de ellos, una vez puesto en Veracruz, alguna cosa para su viaje, había contestado admitiendo la conveniencia; y que respecto a decir se hallaba ya en Veracruz, proponía al venerable cabildo, si en caso de pedir alguna cantidad debería mandársele; y oido por los señores, dijeron que a cuenta de su sueldo y puesto de acuerdo con nuestro ilustrísimo prelado, podría remitirle hasta trescientos pesos; con lo que se concluyó este pelícano que firmó el señor deán (Archivo del Venerable Cabildo Angelopolitano. Actas de Cabildo, Libro 49, f. 31v.-32, con número de registro PUE 54000590) ${ }^{18}$.

Dicha transcripción no se incluía en el estudio de Franco Gutiérrez, aportando, ahora, nueva información al respecto, que atribuye la asunción del cargo de maestro de capilla por parte de Cayetano. Sería aquí donde se modificaría una "pequeña" parte de la historia musical de la propia catedral. Así pues, después de todo lo dicho, y a partir de la transcripción anterior se desprende que, efectivamente, y al contrario de lo que habían anotado investigaciones previas, Cayetano Pagueras habría aceptado el cargo de maestro de Capilla de la catedral de Puebla llegando a desplazarse a Veracruz (en la costa caribeña-atlántica) para tomar posesión de esta. Es por ello, por lo que tal conclusión es, sin más, un mero dato dentro del periplo musical en la actividad de la catedral angelopolitana, como también una nota más en la biografía de Cayetano puesto que, como se verá, el cargo aceleraría el devenir de los hechos. Dicho nuevo dato corrobora y justifica, más si cabe, la presencia de las partituras de Cayetano en la catedral pueblana, como ya antes se había anotado.

Quedará pues, ya para otras investigaciones, aclarar algunos asuntos tales como los de la fecha exacta de la asignación del cargo y la renuncia. ¿̇, en cambio, podría aceptarse la fecha anterior de 24 de marzo de 1791 como fecha válida? Además, quedará también pendiente de consultar in situ, y poder así deliberar, qué partitura de las conservadas en Puebla formaría parte de la oposición que la historiografía había aceptado como válida de 1791 o si, en cambio, serían partituras, siguiendo con la idea de Escudero y Franco, de que las fuentes existentes en Puebla formarían parte de los documentos que Cayetano enviaría con motivo de sus aspiraciones. Lo replanteado ahora, con la asignación, al menos nominal del puesto de maestro de capilla plantea una necesaria revisión de los manuscritos musicales, puesto

${ }^{18}$ Información extraída de la base de datos de la Universidad Nacional Autónoma de México, op. cit. [fecha de consulta: 13.08 .2020$]$. 


\section{JOAN BENAVENT PEIRó}

que, tal vez, la Misa de Cayetano fechada en 26 de julio de 1791 vendría ya como un material fruto de su "supuesto" ejercicio en el magisterio de música. Incluso, todavía continuando con las hipótesis, podría plantearse que el adelanto económico que el cabildo le había realizado podría haber estado motivado por el envío, por correo, de algunas obras de Pagueras al capítulo poblano, como práctica habitual en la época. En este sentido, el cabildo podría haberle ofrecido dicho adelanto, ya de su propio salario, como muestra de agradecimiento del envío de las composiciones, a la vez que serviría para "asegurar" el puesto para el músico, que hubiera podido optar por otro destino diferente que le pudiera resultar más beneficioso. En cualquier caso, como antes, no dejan de ser, al menos de momento, meras especulaciones.

Pero, por si no era poco, quedan un par de elementos que vuelven a mostrar el citado período de interinatos en que se encontraba el cabildo, aun asumiendo por válida la hipótesis anterior en la que Cayetano ya fuese maestro de capilla poblano. En dicho supuesto, Cayetano estaría en Veracruz no pudiendo llegar a Puebla, al menos, desde el 24 de marzo, por lo que el "ambiente" en la capilla angelopolitana podría considerarse enrarecido.

Unos meses después de su llegada a Veracruz, el 22 de julio de 1791, explica Franco Gutiérrez, llegaba a la catedral de Puebla un memorial de José Fallotico (o Facotillo como aparecía en el documento del cabildo) ofreciéndose al cargo de maestro de capilla. Aspirante que, al parecer, se considera que fue rechazado al no haberse encontrado más referencias al respecto.

Según parece, y con relación a la supuesta oposición de Cayetano de 1791 en Puebla, todo lo dicho hasta aquí podría resumirse diciendo que desde la fecha del 10 de diciembre (en que el obispo Biempica había dado instrucciones de esperar una respuesta de Cayetano), el cabildo le avanzaba 300 pesos en fecha de 24 de marzo de 1791, habiendo dicho músico aceptado el cargo. Aunque todavía no se había presentado en Puebla.

Podría suponerse que desde el cabildo ya le estuviesen exigiendo composiciones. Muestra de ello podría haber sido la Misa fechada en julio. Con el paso del tiempo, y sin haber llegado Cayetano a Puebla, el cabildo recibía un memorial de Manuel Arenzana, recién llegado de España, para presentarse al cargo de maestro de capilla. En dicho documento, visto en la sala capitular de Puebla en fecha de 26 de agosto de 1791, Arenzana alegaba ser natural de Soria y "ser facultativo en el pianoforte y maestro compositor de música". A su vez, anunciaba que "noticioso de hallarse vacante el magisterio de capilla del coro" se ofrecía dispuesto a presentarse y ser examinado según pareciere al cabildo (Franco, 2019, p. 62).

Ante tal hecho podría considerarse que no teniendo noticias de Pagueras, el cabildo hubiese abierto de nuevo una convocatoria pública o que, en cambio, sabedores los músicos del período por el que pasaba el cabildo, desde la renuncia al cargo de José Joaquín Lazo Valero, que la noticia hubiese podido viajar más allá del atlántico rumbo a la península, produciéndose así una doble interpretación del asunto. ¿Tal vez rocambolesca? Mientras en Puebla esperaban la llegada de Cayetano, la noticia de la vacante en la catedral de Puebla producida por Lazo Valero podría haber llegado a oídos de Manuel Arenzana y haber optado 


\section{Nuevos datos biográficos de CAYETANo y BRUno Pagueras. DE BARCElona A LA HABANA Y A LA SEU D'URGELL, RESPECTIVAMENTE}

este por presentarse al cargo, no sin antes haber gestionado otro trámite en la península, previo a su partida hacia la colonia.

La cuestión, documentada una vez más por Franco Gutiérrez, es que Cayetano Pagueras no pudo permanecer por mucho tiempo más en Veracruz. ¿Acaso se le acabarían los 300 pesos que tenía adelantados? Fuera como fuese, Cayetano escribía al cabildo de Puebla desde La Habana comunicándoles que había vuelto de Veracruz a La Habana y que, gustoso, aceptaría volver, siempre que se le admitiese de nuevo. La nota, con fecha de 2 de septiembre de 1791, decía lo siguiente:

[f. 1r /2r] [Extremo superior derecho: 1a] Certifico qe. en el libro de cabildo N. 48 esta uno tenido en dos de septiembre de mil setecientos noventa y uno y en el una acta del tenor siguiente. [Margen izquierdo: N.7/ set ${ }^{\text {bre }} .2$ de 91] Con citación ante qien [sic.] para determinar sobre la pretencion $q^{\text {e. }}$ hase del magisterio de la capilla $D^{\text {n. }}$. Manuel Arenzana, hecha la corrte. a ntro $\mathrm{Ym}^{\circ}$ prelado $\mathrm{q}^{\mathrm{e}}$. se remite a lo $\mathrm{q}^{\mathrm{e}}$. disponga el V. Cabdo. el sor. Conde manifestó una carta $\mathrm{q}^{\mathrm{e}}$. desde la Havana le dirije $\mathrm{D}^{\mathrm{n}}$. Calletano Pagueras disculpándose de haverse vuelto de Veracruz, y esponiendo estar resuelto a venir siempre qe. le admita este V. Cabdo. Se leio asimismo otra en $q^{e}$. $D^{n}$. Jose Facotillo desde dha Havana pretende dha plaza y con presencia de todo, y principalm ${ }^{\text {te }}$. del deseo $q^{\text {e. }}$ manifestó el V.C. de que ntro $\mathrm{Ym}^{\circ}$. prelado se asumiera el cargo qe. se dignó tomar sobre si de el arreglo de la Capilla, se acordó comisionar a el Sor. Dean $\mathrm{p}^{a}$. $\mathrm{q}^{\mathrm{e}}$. tratándolo todo con S.S.Y. y principalm ${ }^{\text {te }}$. sobre la reasumpcion de el encargo, con lo $\mathrm{q}^{\mathrm{e}}$. S.S.Y. resolviera, informara al V. Cbdo. y en caso de ser el examen del pretendiente qe está en esta ciudad, se citara para tratar el modo del cómo se debía hacer./ Es copia de la acta $\mathrm{q}^{\mathrm{e}}$. refiere, $\mathrm{q}^{\mathrm{e}}$. saqué para constancia en el exped ${ }^{\text {te }}$. de la materia. Ángeles enero nueve de mil setecientos noventa y dos. / Lic. Joseph Fernando Baldomar./ Secet ${ }^{\circ}$. [Firmado y rubricado] (Franco, 2019, p. 129).

Del memorial anterior puede leerse, además de la nota sobre Pagueras, la aspiración antes comentada de Facotillo y la agilización de los trámites para poder examinar al recién llegado Manuel Arenzana, que acabaría siendo el maestro de capilla de la catedral de Puebla.

Según se desprende de lo visto hasta aquí, podría plantearse que Cayetano Pagueras habría llegado a ocupar el cargo de maestro de capilla por asignación directa, por recomendación del obispo poblano Biempica a finales de 1790, puesto que no hay constancia de que se hubiese presentado a ningún ejercicio. Merecería, pues, revisar las composiciones conservadas y las fechas de estas, así como las marcas de agua de los pliegos, etc. para poder continuar la investigación, dado que las conclusiones aquí sacadas merecen materiales complementarios para poder, finalmente, ser corroboradas. En tal caso, la horquilla temporal inicial ante dicho "supuesto" cargo abarcaría las fechas comprendidas entre el 10 de diciembre de 1790, momento en que el obispo mandaba esperar a sus comisionados, pasando por la fecha de 24 de marzo de 1791, en que el cabildo acordaba avanzarle 300 pesos de su sueldo y, finalmente, el 2 de septiembre de 1791 en que Cayetano Pagueras comunicaba al cabildo la renuncia, o al menos, su regreso a La Habana. 


\section{JoAn Benavent Peiró}

Volviendo al tema tratado, ante tales circunstancias, esto es, con Pagueras de vuelta en La Habana y habiendo rechazado al aspirante Facotillo, el cabildo, ahora ya en fecha de 6 de septiembre de 1791, acordaría mandar componer a Manuel Arenzana, dado que se encontraba en la ciudad, los kyries de una misa y de un motete de canto llano. Dicho acuerdo ha pasado a la historiografía como el de las oposiciones de acceso al cargo de maestro de capilla de la catedral de Puebla de Manuel Arenzana. Para tal ocasión, también intervinieron las composiciones de Cayetano Pagueras. Fue entonces cuando el cabildo, teniendo las composiciones de Arenzana, anotaba de mano de su secretario:

y con las piezas qe a nombre del compositor Pagueras, recidente en la Havana, ha presentado en este cab ${ }^{\text {do }}$. el Sor. Conde, copiadas de una misma nota, $\mathrm{p}^{\mathrm{a}}$. $\mathrm{q}^{\text {e. }}$. no se sepa el autor de ellas, se remitan ambas composiciones a el Rdo, Padre Cuzalegui [Crucelaegui] (Franco, 2019, p. 130).

¿Acaso Pagueras estaría volviendo a aspirar a la plaza de maestro de capilla? O, en cambio ¿Se utilizarían sus composiciones, de manera anónima, para poder así comprobar la validez del otro aspirante, por comparación con los materiales de ambos?

Para tal ocasión, el cabildo, mediante sus comisionados, había nombrado al padre franciscano fray Francisco Martín de Crucelaegui $\left({ }^{*} 1720 \text { c; } † 1802 c\right)^{19}$ como evaluador de las piezas. Sería así como, según relata Franco Gutiérrez, en fecha de 12 de octubre de 1791, el futuro examinador escribía al cabildo anunciándoles la aceptación del encargo para validar el examen. Y una semana después de haber recibido el encargo, el 19 de octubre de 1791, Crucelaegui emitía su dictamen ${ }^{20}$, descalificando la obra de Cayetano y otorgando el cargo de maestro de capilla de Puebla a Manuel Arenzana. De Cayetano, el censor anotaba lo siguiente:

que el Autor de el que en su vi[da] aprendio la Composición con Maestro, sino que las tales obras son travesuras de puro ingenio echas a costa de muchos calentamientos de cabeza/ y de un trabajo improvo, por haber visto ó leido/ algunos Autores que tratan de Obras de Composición; mas no por eso el halla llegado á compren/ derlas, pues sus Piezas estan defectuosisimas a tanto grado, que no solo no merece el nombre de Com/positor, pero ni aun el de verdadero Contrapuntista (Franco, 2019, p. 67).

\footnotetext{
${ }^{19}$ Fray Francisco Martín de Crucelaegui (o Cruzelaegui según la manera “antigua” de escribir el apellido) fue un organista y compositor religioso de la orden franciscana, llegado a México con las Misiones de San Fernando, siendo ya compositor. Ejerció el cargo de organista en la catedral y en el Colegio de San Fernando en México, entre 1773 y 1775, y en la entonces iglesia parroquial de Guadalupe en México. Se conservan obras suyas en el Archivo Capitular de Guadalupe. Según E. Thomas Stanford, su estilo musical mantiene la esencia del género italiano de la battaglia (Guerberof, 2007, p. 268; Pareyón, 2007, p. 295).

${ }^{20}$ ¿Sería dicho veredicto la carta a la que se referiría Gabriel Pareyón al referirse a Arenzana en la entrada biográfica del franciscano? (Pareyón, 2005, p. 295).
} 
Nuevos datos biográficos de Cayetano y Bruno Pagueras. DE BARCElona A LA HABANA Y A LA SEU D'URGELL, RESPECTIVAMENTE

La cuestión será dilucidar, aceptando que Cayetano ya había sido nombrado maestro de capilla, al menos nominalmente, qué hacían sus papeles entre los documentos evaluados (¿serviría la hipótesis anterior del agradecimiento económico del cabildo por haber escrito unas piezas como maestro de capilla compuestas antes de su llegada a Puebla?). Además, hay otro asunto que complica, todavía más, el proceso en cuestión. Al parecer, ambos músicos, Cayetano primero y Arenzana después, contaron con una recomendación para optar a la plaza de maestro de capilla de la catedral mexicana. El primero contó, como viene anotado, con la protección del obispo Biempica, que, se asumía con anterioridad, le valdría para poder contar con el cargo de maestro de capilla; mientras que el segundo, obtuvo la recomendación de un tal Mathias Mendíburu, quien escribiría una carta de recomendación de Manuel Arenzana para el evaluador Crucelaegui. Carta, por cierto, que ya iría, desde España, primero a Veracruz y después a Puebla, redactada previa a la partida española desde Cádiz con la fragata La Dolores, alias "La afortunada", y con los utensilios que Arenzana se llevaría desde España. Lo anecdótico de la cuestión es que Arenzana, que contaba ya con 41 años, aprovecharía su experiencia (acaso previa a la de músico) para viajar en la fragata como mozo de repostería y que, a su llegada a Puebla, y después del examen, acabaría convirtiéndose en maestro de capilla de la catedral angelopolitana.

Dichos datos los aporta, una vez más, Franco Guitérrez en la transcripción de una carta en la que Arenzana mandaba a su mujer, desde Puebla, indicándole los trámites que esta debía realizar antes de su partida desde Sevilla a Nueva España. En la carta, además de encomendarle a su mujer que se trajera unos "rondóes ([del] padre Soler) tan primorosos por su estilo de los que yo le he oído tocar”, le pedía agradecer a un tal Ramón Bonrostro las gestiones realizadas por haberle facilitado la carta de Mathias Mendíburu para el padre fray Martín Francisco de Crucelaegui diciendo:

Por la estrechez del tiempo que no tengo lugar de escrivirles en particular, y así que tengan esta por suya, como también digo lo mismo por $\mathrm{D}^{\mathrm{n}}$. Ramón Bonrostro, dandole las devidas y repetidas gracias por el singular favor que me hizo de facilitarme la carta de $\mathrm{D}^{\mathrm{n}}$. Mathias Mendíburu, [...] para el R ${ }^{\mathrm{mo}}$. P. Fray Martín Franco. de Cruzelaegui, quien ha sido mi sinodal (Franco, 2019, pp. 64 y 122).

La citada recomendación que el desconocido Mathias Mendíburu haría de Manuel Arenzana para el examinador Crucelaegui también había quedado anotada por Pareyón, diciendo que Arenzana "obtuvo la plaza de maestro de capilla del mencionado templo gracias a las recomendaciones del presbítero y músico Martín de Cruzelaegui” (Pareyón, 2003, p. 73). En esta línea, Franco Gutiérrez apunta que "no es posible saber si la opinión de Crucelaegui estaba sesgada por la carta de recomendación de Mathias Mendíburu a Arenzana [...]” (Franco, 1019, p. 68).

De todo ello, Alejo Carpentier resumía el asunto con un "tono" más literario que académico diciendo que Cayetano Pagueras: 


\section{JoAn Benavent Peiró}

Invitado cierta vez a trasladarse a Puebla de los Ángeles, la nostalgia del trópico no le había dejado terminar el viaje. Al presentarse a oposiciones, se ufanaba de ser maestro en las cuatro artes: canto llano, órgano, contrapunto y composición (Carpentier, 1941, pp. 110-111).

Así pues, después de lo anotado y en conclusión al supuesto examen de 1791, ha quedado visto cómo Cayetano Pagueras llegó a ser maestro de capilla de la catedral angelopolitana, al menos de manera nominal. No obstante, dicha afirmación merecería un estudio pormenorizado para averiguar qué obras de las conservadas pudieron escribirse para el desempeño de su magisterio de capilla en Puebla (en el hipotético caso de que eso hubiera llegado a suceder), y cuáles serían, simplemente, fruto de que las hubiera enviado desde otro lugar con motivo de pretender acceder a dicho magisterio de capilla. $\mathrm{O}$, incluso, que se hubieran podido copiar con posterioridad, aunque en época del propio compositor, acaso por la fama que llegara a alcanzar en el ámbito de su profesión, y más allá de las fronteras hispano-cubanas con las que tradicionalmente se le asocia.

Para tal asunto, debería mantenerse la hipótesis según la cual el examen de Arenzana de 1791 merecería la presencia de Cayetano, por un despecho del cabildo al haber renunciado este al puesto de su magisterio de capilla, motivado por su regreso a Cuba. Y, además, la cuestión sería dilucidar si verdaderamente llegó a tomar posesión del puesto en Puebla, trasladándose físicamente hasta esa ciudad, o si ni siquiera llegó a hacerlo (como parece ser que finalmente ocurrió), remitiendo sus ejercicios de examen por correo, y marchándose de nuevo a Cuba, sin llegar a pisar nunca suelo poblano.

Unos años más tarde, el 21 de junio de 1795, un anuncio del Papel Periódico de La Havana sitúa a Cayetano como vecino de la calle Sol núm. 25 de la ciudad de La Habana. En este mismo año obtuvo una plaza de contralto en la capilla de música de la catedral de La Habana, que aprovecharía para intentar acceder al cargo de maestro de capilla en 1802, según se desprende de la valoración del tribunal siguiente, pero que fue en vano, por lo que hubo de resignarse con la plaza de contralto segundo:

el enunciado Sr. Dean requirió a los examinadores para que expusiesen el juicio que formaban de él quienes unánimemente dijeron que por lo que mira a la especulativa lo hallaban y reputaban cumplidamente instruido y en ella lo aprobaban pero que también juzgaban no era apto para maestro de capilla, porque es constante que el arte es vano sin la naturaleza; que la voz del [dicho] D. Cayetano era notoriamente desagradable; que no podía darle la extensión que en un muchos casos sería conveniente y aún necesario, pues por razón de su encargo debía suplir la voz que el acto de estarla ejerciendo faltase [Acta del 16 de diciembre de 1802: tomo 2, folio 55v.] (Escudero, 1998, p. 43). 
Nuevos datos biográficos de Cayetano y Bruno Pagueras.

DE BARCElona A LA HABANA Y A LA SEU D'URGELL, RESPECTIVAMENTE

Tal informe sorprende al anteponerlo al hecho de que Cayetano - que perdería la oposición de 1802- compondría piezas por encargo para el ganador del examen, el músico Manuel Lazo de Vega (fl. 1802), quien pasaría a ser el maestro de capilla ${ }^{21}$. Composiciones que este último le pagaba a Cayetano "de su propio bolsillo" (Escudero, 1998, p. 42 y 2015). Según un acta del 29 de diciembre de 1802, relata Escudero, Pagueras quedaría como contralto segundo de la capilla habanera hasta el 14 de noviembre de 1806.

Para la última fecha referida, Juan Nepomuceno Goetz (fl. 1802-1809) renunciaba al cargo de maestro de capilla de la catedral de La Habana. Ocasión que el cabildo de la catedral aprovecharía para asignarle al barcelonés "el recibo y cuidado de los papeles, instrumentos y demás, correspondiente a dicha capilla", además de ofrecerle el encargo de los tiples y de la dirección "de dicho cuerpo" (Escudero, 1998, p. 43). Es por ello, por lo que podría afirmarse que Pagueras ejerció el cargo de maestro de capilla interino desde el 14 de noviembre hasta el 16 de diciembre de 1806, fecha en que Juan Nepomuceno pedía al cabildo la readmisión en su cargo anterior.

No se ha podido localizar más información alrededor de la breve estancia de Pagueras al cargo de la capilla habanera. Dicho dato plantea la posibilidad de que el cabildo encargase la responsabilidad de cumplir las funciones de maestro al mismo Cayetano, en calidad de buen conocedor de las prácticas y costumbres propias del centro. Dicha práctica era habitual en la época, asignando a algún cantor antiguo de la capilla, como buen conocedor de las prácticas y costumbres del centro en cuestión, las tareas propias, o en mayor medida, una parte de ellas, del maestro de capilla. En el caso de Pagueras, él mismo venía ejerciendo el cargo de cantor y, por tanto, ya conocería el funcionamiento de la capilla. E incluso, yendo un poco más allá con la hipótesis, plantear la posibilidad de que el mero hecho de que Pagueras le hubiese sustituido en el cargo sentase mal a Goetz, por el mero hecho de ser un

\footnotetext{
21 Alejo Carpentier anota otro examen posterior en 1803 para el puesto de maestro de capilla de la catedral de La Habana [del que no se han encontrado coincidencias con el resto de la bibliografía, y que, por tanto, merecería un estudio más detallado dada la presencia de apellidos en el relato de Alejo que no se encuentran en el resto de las investigaciones actuales]. El motivo del supuesto examen venía dado por la jubilación del entonces maestro Francisco María Lazo de la Vega, que había ocupado el cargo desde 1796, cuando se fundó la capilla musical de la catedral. La referencia a dicho maestro ofrece cierta confusión, dado que los estudios recientes anotan a un tal Manuel Lazo de [la] Vega como maestro de capilla de la catedral habanera por aquellos mismos años, pudiendo suponer por ello un error de Carpentier. En cualquier caso, para la ocasión se presentaron al cargo, según Carpentier, José Francisco Rensoli (cubano y natural de Trinidad) [y quien, como después se verá, sería maestro de la catedral de 1809-1845 e introdujo, por primera vez, músicos negros en la capilla], Luis Lazo (primer violín de la capilla), Cayetano Solís y Cayetano Pagueras, en un primer momento, aunque se les uniría poco tiempo después Juan Nepomuceno Goetz [maestro de capilla en la catedral en 1803-1809, con un breve reposo intermedio — cargo que ocupó hasta que se marchó de Cuba-]. La cuestión es que, según Carpentier, para la supuesta oposición de 1803, el citado Juan Nepomuceno también ofrecería sus servicios para la plaza en cuestión, ante lo que el cabildo le nombró maestro de capilla interino, cosa que crispó los ánimos del resto de los aspirantes. Ante la tensa situación, Carpentier continúa relatando que el recién llegado director de capilla se vería forzado a redactar unas apreciaciones sobre sus contrincantes, poco, o más bien, nada objetivas, en las que Cayetano recibiría unas afirmaciones que vilipendiarían el futuro devenir del barcelonés: "segundo contralto; voz malísima, sin expresión. Casi ciego. En cantando, todo el mundo se pone a reír y los perros huyen de la iglesia. Buen compositor y muy asistente, pero sus propias obras no sabe cantar" (Carpentier, 1941, p. 113). A pesar de las valoraciones que se formularon sobre su figura, y gracias al trabajo de los últimos años, la pésima y aun malintencionada valoración de Juan Nepomuceno sobre Pagueras ha ido mereciendo nuevos enfoques, hoy más objetivos, gracias al trabajo, en mayor medida, de Miriam Escudero. Aun así, nunca ya podremos llegar a conocer la verdad sobre la calidad vocal del músico que llegó a ejercer el cargo de contralto.
} 


\section{JoAn Benavent Peiró}

subordinado suyo, tal vez con pretensiones de arrebatarle el puesto. En definitiva, un usurpador de sus atribuciones y funciones, de donde, tal vez, sus descalificaciones hacia Pagueras. Al fin y al cabo, pasado un breve tiempo, el mismo Nepomuceno Goetz pedía al cabildo la readmisión en el cargo de maestro de capilla.

Dicho dato alrededor de la posible asunción, corta, del cargo de maestro de capilla de la catedral de La Habana, amplía el listado de los maestros de capilla habaneros dentro del período visto ${ }^{22}$, que serían: Manuel Lazo de la Vega (1796-1803), Juan Nepomuceno Goetz (1803-1809), con una breve ocupación del cargo por Cayetano Pagueras (14.11.180616.12.1806), Francisco Rensoli (1809-1845) y, ya en la segunda mitad del siglo, Francisco de Asís Martínez (1862-1872).

La relación del catalán con el cabildo se mantuvo, según Escudero, hasta 1807, momento en que presentó su renuncia a una suplencia que ejercía como organista (Escudero, 2013a, 2015). Según parece, a partir de las referencias encontradas en la bibliografía consultada, Pagueras ocuparía, después de su breve cargo como maestro, el puesto de organista de la catedral, al que renunciaría en la citada fecha de 1807.

Después de lo visto, podría suponerse que la relación Goetz-Pagueras no debió ser precisamente buena. A su vez, al tiempo de finalizar su supuesto magisterio (¿cómo sustituto o suplente o, tal vez, cómo interino?) Pagueras renunciaría al cargo de organista y también el propio Goetz se marcharía dos años después. Cabe plantear la posibilidad de que al quedar como organista tratase a diario con el maestro de capilla Nepomuceno Goetz actuando tanto con la propia capilla como en solitario, como resultante de su cargo de organista, motivo que acrecentaría las diferencias entre ambos.

Dicha información contrasta con la aportada por Fuentes, quien todavía lo mantendría en el cargo de organista hasta 1821 (Fuentes, 1981, p. 125). En dicho nuevo supuesto, podrían plantearse dos posibles escenarios. Para el primero, tal vez Cayetano, después de la experiencia, ya no hubiera querido ocupar el cargo de maestro de capilla y esquivar así posibles problemas, habiéndose contentado con su papel de organista. En cambio, para el segundo, podría haber sido el mismo cabildo quien, habida cuenta de la mala experiencia pasada (además de contar con un Cayetano casi ciego, como anotaba Alejo Carpentier y con problemas con otros miembros de la capilla musical) hubiera preferido no contar con él como nuevo posible maestro de capilla (dado que una cosa es cubrir el puesto temporal, puntual o momentáneamente, y otra bien distinta ocupar el cargo como titular, con sus respectivas responsabilidades).

Además de los acontecimientos acaecidos con motivo de sus aspiraciones en México y de su vinculación con la catedral de La Habana, durante su estancia isleña, su vida profesional también estuvo vinculada al convento de La Habana de la Orden de los Hermanos Betlemitas. Por último, según la Guía del profesorado cubano para 1868 de Mariano Dumás, Cayetano Pagueras trabajó en el colegio privado de San Francisco de Asís (de segunda enseñanza, nacional y extranjera), en La Habana. Allí se encargó de la prefectura, la

\footnotetext{
${ }^{22}$ En el trabajo de Pearce (2016, p. 43) no aparece el breve período de Cayetano Pagueras. Incorporándose aquí a partir de la bibliografía consultada.
} 
Nuevos datos Biográficos de Cayetano y Bruno Pagueras.

De Barcelona a La Habana y a La Seu D’Urgell, ResPectivamente

organización del centro, de los estudios y de la disciplina escolar. Situación laboral de la que, de momento, no hay constancia sobre las fechas concretas en que ejerció los citados cargos, puesto que el volumen en cuestión no los detalla (Dumás, 1868, pp. 92-94).

De los datos biográficos anotados puede apreciarse el interés que la producción musical de Pagueras suscitó entre sus contemporáneos. No solo tuvo que componer piezas para el maestro de capilla habanero Manuel Lazo de Vega, quien, como se anotaba, pagaba al catalán las composiciones. Además, desde Puebla de los Ángeles, el mismo obispo Biempica optaba por esperar la respuesta del catalán, antes de continuar con los procedimientos de selección para un nuevo maestro de capilla. Otros datos amplían, además, la recepción que se realizó de las obras del compositor, que se perpetuaría en la isla hasta el final del período en que Francisco de Asís Martínez — que sería el maestro de la capilla de la catedral de La Habana entre 1862 y el fallecimiento del mismo- accedía al cargo. Dicho aspecto ha sido tratado ampliamente por Escudero en su catálogo del archivo de La Merced, op. cit.

Además, Francisco de Asís Martínez escribía una carta ${ }^{23}$ al cabildo de La Habana, el 6 de marzo de 1872, donde anotaba que, hasta su llegada al puesto habanero, las únicas obras que se interpretaban en la catedral eran las del catalán. En concreto el maestro Martínez, según transcribe Pearce Pérez, escribía al cabildo diciendo:

Dolorosa sensación me causó al hacerme cargo de el archivo, porque a la vez que me cercioraba de su pobreza en número de obras, y lo informal de su inventario se manifestaba ostensiblemente un lamentable abandono, una vituperable indolencia, o tal vez una indisculpable ignorancia. Con rarísima excepción no contenía más obras que las que compuso D. Cayetano Pagueras, Organista que fue de los PP. Belemitas ${ }^{24}$, cuyas fechas datan del año de 1795 al de 1805; y más admirará V. E. Y. al saber que, después de tantos años que hace se formó aquel repertorio, [que] solo se ejecutaban aquellas mismas obras, por no haber otras, en el año [18]62 en que entré yo a regir la Capilla, sino que también con los mismos papeles que se escribieron en aquella época, papeles rotos y desgastados por el uso y la acción del tiempo (Pearce, 2016, p. 36).

En cuanto a su producción musical, un inventario de la catedral documenta la presencia de cierto número de composiciones de Pagueras en 1872, en la misma catedral de La Habana. El inventario en cuestión forma parte de la carta, ahora vista, que Francisco de Asís Martínez escribiría al cabildo habanero. Dicha información había aparecido publicada, aunque de manera resumida, en 1946 por Carpentier, quien anotaba en ochenta el número total de

\footnotetext{
${ }^{23}$ Pearce Pérez anota la localización concreta en el Archivo de la catedral de la Habana con la signatura: HAC, Carpeta 1. «Carta de Francisco de Asís Martínez sobre el archivo de la catedral», de 6 de marzo de 1872 (Pearce, 2016, p. 34).

${ }^{24}$ Si la Guía del profesorado cubano para 1868 de Mariano Dumás (1868, pp. 92-94) anotaba una vinculación de Cayetano Pagueras de tipo académico con el convento de La Habana de la Orden de los Hermanos Betlemitas, la nota aquí vista detalla el ejercicio del cargo de organista por parte de Cayetano, asumiendo, que fue organista del convento.
} 


\section{JoAn Benavent Peiró}

composiciones del compositor catalán presentes en el escrito, dándolas el célebre escritor cubano por perdidas, en el año de la publicación del texto. Además, el musicólogo y periodista señalaba las fechas de 1794 y 1801 como el período comprendido para la composición de las composiciones [período aproximado al que anotaba Francisco de Asís en la carta antes vista] (Carpentier, 2001, pp. 135-141). Fue Escudero quien, en su estudio de El archivo de música de la iglesia Habanera de la Merced, respaldaba sus hallazgos basando una parte de su investigación en dicho inventario e incluía el título de este, que dice así: "Índice general de las Obras de Música que contiene el archivo de la Capilla de la Santa Iglesia Catedral de la Habana, formado en febrero de 1872 por el Pbro. Francisco de Asís Martínez, Maestro de Capilla en la referida Santa Iglesia" (Escudero, 1998, p. 42). Recientemente, la investigación de Pearce Pérez (2016, pp. 37, 41) ha actualizado los datos ofrecidos con anterioridad. En total, son setenta y tres las composiciones de Bruno Pagueras que se encuentran en dicho inventario.

Una parte de las composiciones de Cayetano Pagueras proceden de la catedral de La Habana, que a lo largo del siglo se han repartido en diferentes fondos. Del total de su producción localizada, ocho partituras suyas se encuentran en la iglesia habanera de La Merced. De las cuales, algunas han llegado a nuestros días como arreglos realizados por Francisco de Asís Martínez. Hay tres composiciones más en la iglesia de San Francisco de Asís de La Habana. En el convento de Nuestra Señora de Belén de La Habana ${ }^{25}$ se localizaron dos misas escritas en un cantoral de pergamino, que se conservó en la biblioteca de la compañía del Sagrado Corazón de Jesús y San Ignacio de Loyola, actual sede de la Compañía de Jesús (Escudero, 1998, 2013a, 2013b, 2015, 2016). Además de los esfuerzos de Miriam Escudero, con la publicación del catálogo de los archivos de música de las catedrales de México y Puebla de los Ángeles, realizado por Thomas Stanford (2002) y más tarde por Lucero Enríquez, Drew Edward Davies y Analía Cherñavsky (Enríquez et al., 2014 y 2015), se localizaron nuevas obras del compositor catalán, que han visto una nueva catalogación más reciente (Andrade, et al., 2015, pp. 310, 311, 428). Algunas de las cuales fueron el fruto de la aspiración del músico al citado cargo de maestro de capilla de Puebla de los Ángeles. En ambas ocasiones, Cayetano enviaba cuatro composiciones diferentes, todas ellas autógrafas, dos de las cuales estaban fechadas en 1791. Existe otra composición en la catedral Metropolitana de México, de la que hay una copia posterior (Escudero, 2013a, 2015), localizada por John Lazos (2015), en la Parroquia de San Cristóbal Suchixtlahuaca ${ }^{26}$, hoy dependiente de la diócesis de Oaxaca, y que en otros tiempos lo fue de Puebla de los Ángeles.

En definitiva, la revisión bibliográfica propone una nueva interpretación del periplo biográfico de Cayetano a partir de su llegada a La Habana. Dicha "novedad" se centra en el asunto según el cual Cayetano podría haber llegado a ser nombrado maestro de capilla, se decía antes, nominalmente, gracias a la influencia del obispo Biempica, aunque finalmente no llegara a ejercer sus funciones, puesto que con motivo de su vuelta desde Veracruz a La Habana el cabildo convocaba un examen para validar a quien ha pasado a la historiografía musical como el último maestro de capilla de la época virreinal. A su vez, quedará corroborar

${ }^{25}$ La existencia de obras de Cayetano Pagueras en dicho convento reitera su actividad como organista del convento, como se anotaba unas lineas atrás.

${ }^{26}$ RISM ID no., 120000351. 
Nuevos datos biográficos de Cayetano y Bruno Pagueras. De Barcelona a La Habana y a La Seu D’Urgell, ResPectivamente

qué partituras de las que se conservan en Puebla serían fruto de su magisterio o de sus motivaciones para aspirar al cargo de maestro de capilla de la catedral angelopolitana.

\section{Bruno Pagueras Portavella ${ }^{27}$}

De Bruno Pagueras, apenas se han realizado estudios con profundidad. SorianoFuertes, quien lo anota como Paqueras, lo incluía, juntamente con otros autores, entre el listado de "sobresalientes compositores, como lo atestiguan las muchas obras que han dejado escritas, y aún se conservan, en los archivos de sus respectivas catedrales" (1855, pp. 249250). A su vez, Baltasar Saldoni —que había sido alumno de Francisco Andreví en la capilla de música de Santa María del Mar y que a su vez había sido alumno del hermano de Cayetano en La Seu d'Urgell (Lleida) - mencionaba que fue un "distinguido maestro de la catedral de La Seo de Urgel a mediados del siglo XVIII, y que dejó escritas varias obras de mucho mérito" (1881, p. 243), datación errónea, puesto que lo fue desde finales del siglo hasta el primer tercio del siguiente.

De sus años al cargo de la capilla musical destacaron dos alumnos que pasarían a formar parte, ya para el siglo venidero, de los mejores puestos del panorama musical español. Condiscípulos y amigos, sus trayectorias profesionales distarían en bandos contrarios. Una, la de Francisco Andreví, por desarrollar una trayectoria profesional de tipo eclesiástico, y, por tanto, arraigada en la tradición escolástica. Otra, en cambio, la del compositor Ramón Carnicer, por representar la música del teatro de ópera del Teatre de la Santa Creu de Barcelona, donde llegaría a ser director y ejerciendo, por tanto, una parte de su carrera como empresario (no como director de empresa, en el término actual, sino como cabeza visible de la oferta cultural llevada a cabo en el coliseo). A pesar de sus divergencias laborales, ambos sentirían respeto el uno por el otro, llegando a coincidir como profesores del Conservatorio de Madrid. Fue en el citado centro donde el de Tárrega todavía utilizaría en 1851 las composiciones que su condiscípulo había creado durante su exilio francés, usándolas como modelo objeto de estudio para los alumnos de composición del propio Carnicer en las aulas del centro educativo (Ballús \& Ezquerro, 2019b, pp. 97-98).

Volviendo al caso del maestro de ambos destacadísimos músicos, la producción musical de Bruno Pagueras, hoy cercana a las doscientas composiciones religiosas localizadas, se encuentra repartida entre el archivo capitular de La Seu d'Urgell, los archivos catedralicios de Girona, Córdoba y Tarragona, y en diferentes parroquias como la de Sant Joan de les Abadesses (Girona), Santa María del Pino, en Barcelona, y la parroquial de Sant Pere i Sant Pau de Canet de Mar (Barcelona). Además, se encuentran composiciones suyas en el Arxiu Comarcal de la Segarra, en Cervera (Lleida), y en la Biblioteca de Catalunya, también en Barcelona. Como puede verse, todas ellas en Cataluña, a excepción de algunas composiciones que se han localizado en la catedral de Córdoba. En este sentido, las numerosas publicaciones de inventarios y catálogos, algunos todavía en curso, como el del archivo capitular de la

\footnotetext{
${ }^{27}$ Se reúnen aquí, tan solo, algunos de los aspectos biográficos del compositor, esperando poder presentar nueva documentación de archivo en el momento de la defensa de mi tesis en curso, op. cit:: La música en el Bisbat d'Urgell entre 1767-1836 i el seu referent catedralici...
} 


\section{JoAn Benavent Peiró}

catedral de La Seu d'Urgell, han sacado a la luz la difusión de las obras del compositor catalán que trabajó, en su mayoría, al servicio del cabildo urgelense (Civil, 1968, pp. 168, 170; EsterSala \& Vilar, 1987, 1989, 1991; Bedmar, 2009, p. 102; Benavent, 2014; Gregori \& Romeu, 2016).

Como su hermano, empezó trabajando de organista en diferentes conventos, entre ellos el de la Valldonzella de Barcelona y posteriormente en la parroquia de Vilanova de Cuberes, actual Vilanova i la Geltrú. Tras un intento frustrado de acceder al cargo de maestro de capilla del Palacio de la Condesa de Barcelona en 1780, al año siguiente accedía a homónimo cargo en la catedral de La Seu d'Urgell, que mantendría hasta el final de sus días. Durante su estancia urgelense intentó conseguir, también en vano, idéntica plaza a la que ostentaba en el Pirineo catalán, en las catedrales de Jaén, en 1787, y Girona, en 1791 y 1793, sin resultados. En el caso andaluz, Bruno Pagueras solicitaba al cabildo de Jaén el abono de los costes del desplazamiento, que según parece no se aceptaron, puesto que no consta entre los registros de la oposición ${ }^{28}$.

\section{UN MISMO ORIGEN FAMILIAR}

Hasta la fecha ${ }^{29}$, se podía suponer una posible ascendencia familiar, pero la ausencia de trabajos genealógicos al respecto no esclarecía las dudas que ofrecía tal apellido homónimo paterno $^{30}$. Es más, el hecho de que ambos músicos fuesen contemporáneos, y con una producción musical dedicada íntegramente al ámbito religioso, podía aportar una remota relación de consanguinidad, dado su mismo origen catalán. A continuación, se verá cómo la supuesta relación familiar ha quedado demostrada a partir de los datos de archivo localizados.

Para llevar a cabo la investigación se trabajó en el escrutinio del registro de matrimonios de la catedral de Barcelona —una serie documental que, desde 1451 a 1905, contiene miles de referencias a personajes de la diócesis de Barcelona, accesible en un software de reconocimiento de manuscritos textuales_- ${ }^{31}$. A tenor de los resultados que aparecían sobre el apellido Pagueras se amplió la búsqueda con los libros sacramentales de los bautizos celebrados en la catedral, no pudiendo consultar los de otras parroquias de la Ciudad Condal por no haberse conservado. Fue en esta primera fase el momento en que pudo localizarse nueva información relacionada con los matrimonios y bautizos de la familia, lo que se amplió con otras referencias de la parroquia de Santa María del Mar de Barcelona, disponibles en el archivo diocesano de Barcelona - por desgracia, la mayor parte de los

\footnotetext{
${ }^{28}$ Entre los autores que han abordado la obra y la figura del maestro de capilla urgelense, aparte de los ya mencionados, se encuentran: Pujol (1984); Jiménez (1998); Llorens (2001); Ballús (2004); Roig (2004); González (2007); Marín-López (2007); Benavent (2014); Ballús \& Ezquerro (2016); Benavent (2014, 2018, 2019, 2020); y Ezquerro (2020).

${ }^{29}$ Se había publicado con anterioridad sobre el tema (Benavent, 2014), siendo el presente estudio el que aporta nuevos documentos al respecto.

${ }^{30}$ Las variantes lexicográficas encontradas en las fuentes de archivo se han visto replicadas en la bibliografía actual, normalizando el apellido a Pagueras, como aparece en los materiales autógrafos de ambos músicos. Así, entre las formas en que se encuentra el apellido constan las siguientes variantes: Paguéras, Peguera, Pegueras y Pegueres.

31 Agradezco a la archivera Imma Ferrer del Archivo Capitular de la catedral de Barcelona las ayudas prestadas durante el transcurso de la investigación.
} 
Nuevos datos biográficos de Cayetano y Bruno Pagueras.

DE BARCElona A LA HABANA Y A LA SEU D'URGELL, RESPECTIVAMENTE

fondos de la parroquia se destruyeron durante la Guerra Civil española pero, entre los conservados, he podido localizar el certificado matrimonial de los progenitores de los hermanos Pagueras- La investigación continuó, ya en una segunda fase, con la ampliación del material de archivo localizado a partir de fuentes paralelas de escritos musicales de interés y con otros documentos, también de archivo, que ampliaban la información inicial. En concreto, la demanda de ordenación sacerdotal de Bruno Pagueras, conservada en La Seu d'Urgell, devolvía a la investigación nueva información sobre algunos de los lugares donde vivió y ejerció el citado músico diferentes cargos musicales. Por último, la documentación se completó con uno de los testamentos localizados del maestro de capilla urgelense ${ }^{32}$, que aportaba, una vez más, su ascendencia familiar, siendo un documento valioso para el cotejo del resto de la documentación localizada.

\section{LA ASCENDENCIA FAMILIAR}

En la fecha de 30 de agosto de 1746, Lorenzo Pagueras y Catarina Portavella, ambos de origen humilde, pedían al obispado de Barcelona el matrimonio en la parroquia de Santa María del Mar ${ }^{33}$. Boda que se celebraría el mismo día en la iglesia de dicha parroquia ${ }^{34}$.

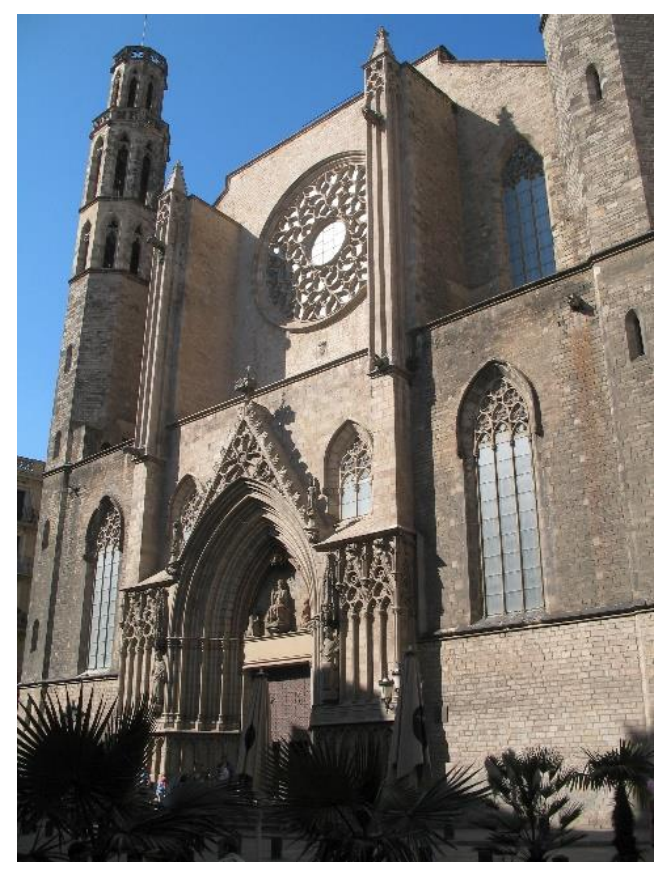

Fig.3: Iglesia de Santa María del Mar de Barcelona, que adquirió el rango de basílica menor en 1923, otorgado por el papa Pío XI.

(C) Túrelio, Wikimedia-Commons, 2008).

\footnotetext{
${ }^{32}$ Documento IX transcrito en el anexo correspondiente al Testamento de Bruno Pagueras Portavella ante el juez de La Seu d'Urgell Joan Juer Albertí, 03.06.1836. E-Bac, Notariales, Varia, Lligall n' 836, 130r. - 130v.

33 Documento I del anexo correspondiente a la demanda matrimonial entre Lorenzo Pagueras y Catarina Portavella al obispado de Barcelona, 30 de agosto de 1746. E-Bc, Llicències d'esposalles, vol. 136. Fol. $19 r$.

${ }^{34}$ Documento II del anexo. E-Bad. Fondos del arcbivo parroquial de Santa María del Mar (Barcelona). Expedientes matrimoniales 1746. Ms. 151.
} 


\section{JoAn Benavent Peiró}

A los dos años, concretamente el 20 de julio de 1748, se bautizaba en la catedral barcelonesa a Isidro Lorenzo José, el primero de los hijos del matrimonio Pagueras Portavella $^{35}$. Tres años después, el 31 de mayo del 1751, nacía el que con el tiempo emigraría a Cuba, que se bautizaría con los nombres de Cayetano Eudaldo Gerónimo, también en la catedral de Barcelona ${ }^{36}$. De Bruno, el tercero de los hermanos, que llegaría a ser maestro de capilla de la catedral de Urgel $^{37}$ —desde 1781 hasta 1836—, no se ha localizado la certificación del bautismo, motivo por el cual, a diferencia de sus dos hermanos, se desconocen el resto de los nombres de pila y la fecha exacta del bautismo. No obstante, a partir del testamento que realizó, y el único localizado de los dos que legó, así como del registro de la defunción del compositor, se ha cotejado, nuevamente, su ascendencia materna y paterna y, a su vez, he podido esclarecer la fecha de su nacimiento en enero de 1753.

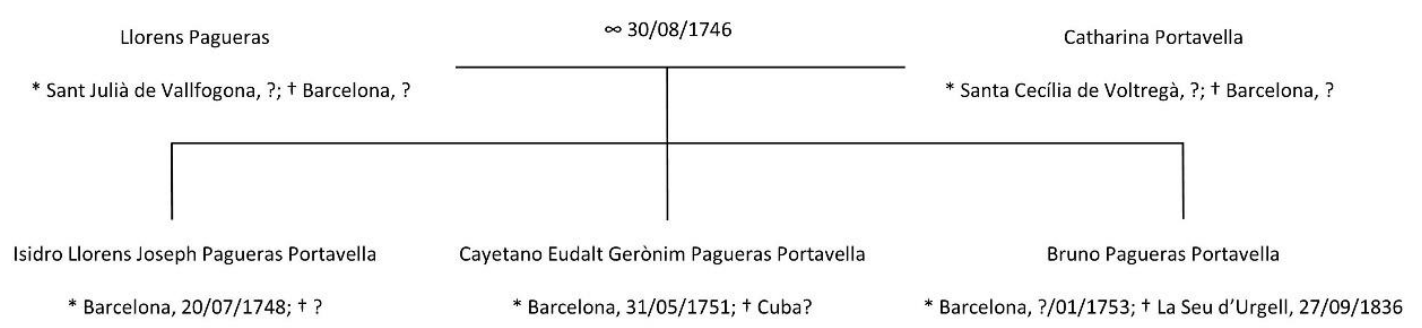

Fig. 4: Árbol genealógico de la familia Pagueras Portavella.

(Elaboración propia).

Es también a partir de los registros de los volúmenes de matrimonios de la catedral barcelonesa, de donde se conoce la aspiración matrimonial de Cayetano, el segundo de los hermanos, con la prometida Raimunda Cervera. La demanda pedía la celebración en la vecina iglesia de Santa María del Pino de la misma ciudad, en fecha de 28 de enero de 1775, cuando el músico contaba con veinticuatro años ${ }^{38}$. Se desconoce la celebración de esta y tampoco se han localizado referencias al respecto en los fondos conservados en la propia parroquia y, por tanto, no puede aportarse ninguna otra información al respecto. ¿Llegaría a casarse con la citada Raimunda en Barcelona? La búsqueda de información al respecto ha sido en vano. No obstante, tal aspecto amplía la referencia vista con anterioridad según la cual Alejo Carpentier sitúa a Cayetano como músico en suelo cubano por matrimonio con una mujer criolla $^{39}$. A tenor de la nueva documentación de archivo localizada el matrimonio criollo

\footnotetext{
${ }^{35}$ Documento III del anexo. $\boldsymbol{E}$-Bc, Libro de bautismos, vol. 23, fol. 138.

36 Documento IV del anexo de los anexos I y II. $\boldsymbol{E}$-Bc, Libro de bautismos, vol. 24, fol. 103.

37 Documento VII: Carta del cabildo de la catedral de La Seu d’Urgell a Bruno Pagueras comunicándole el nombramiento de maestro de capilla de la catedral y la fecha de inicio del cargo. La Seu d'Urgell, 10.03.1781. E-SU, Mn. 967. Libro de correspondencia de 1772 a 1785.

${ }^{38}$ Documento V del anexo: $\boldsymbol{E}$-Bc, Llicències d'esposalles, vol. 151. Fol. 68r.

39 En la Gaceta de la Habana de marzo de 1874, número 52 - 76, tercera sección, se anota un tal Cayetano Pagueras. ¿Sería un hipotético nieto del compositor? La nota detalla lo siguiente: "D. Cayetano Pagueras y Pages, natural de La Habana, soltero estudiante y de 45 años de edad, que se proveyó de cédula en esta Inspección en 23 de enero del año próximo pasado al núm. 808, de comensales manifiesta habérsele extraviado
} 
Nuevos datos biográficos de Cayetano y Bruno Pagueras.

DE BARCElona A LA HABANA Y A LA SEU D'URGELL, RESPECTIVAMENTE

correspondería al de las segundas nupcias de Cayetano. Además, la solicitud de matrimonio en suelo catalán en el citado año estrecha la horquilla temporal para la llegada de Cayetano a Cuba, puesto que la primera noticia del catalán en La Habana es, si no de mayo, de diciembre del 1778, como se mencionaba anteriormente, con motivo de la aspiración del músico a presentarse a la plaza de maestro de capilla u organista disponible en la catedral de Puebla de los Ángeles. Es en el membrete de la carta donde ya se detalla al músico como "Pagueras de la Havana" (Escudero, 2015). Así pues, a partir de los datos encontrados en Barcelona y en La Habana podría asumirse que la partida hacia Cuba estaría comprendida entre el mes de febrero de 1775 y el mes de abril, incluso el de mayo, de 1778.

Por último, otro de los datos existentes en los libros de licencias de esponsales de la catedral de la Ciudad Condal hace referencia al mayor de los hermanos Pagueras. Fue Lorenzo quien el 26 de marzo de 1779 pedía al obispado de Barcelona la celebración de boda con Ignacia Ojeda en la parroquia de Santa María ${ }^{40}$, posiblemente del Mar y no del Pino de la capital catalana, puesto que su entorno familiar formaba parte de la primera.

\section{POSIBLE FORMACIÓN MUSICAL}

Los datos aportados sitúan el bautizo de los hermanos mayores Llorens [Lorenzo] y Cayetano en la catedral de Barcelona, aun perteneciendo los progenitores a la parroquia de Santa María del Mar, como se advierte en los documentos de archivo transcritos en el anexo adjunto. Del tercero, en cambio, de Bruno Pagueras, no se ha conservado información sobre su bautismo. Si el primero ejerció el oficio de chocolatero, según consta en su demanda matrimonial, Cayetano y Bruno se dedicaron a la música, ejerciendo la carrera eclesiástica el último de ellos.

Como en otros aspectos de sus vidas, se desconoce el entorno musical que formó a ambos músicos. No obstante, podría suponerse que la formación de ambos hermanos habría que situarla entre el período comprendido entre la década de 1760 y 1770, fase en la que tendrían entre los ocho y los doce años y estarían, por tanto, en la edad de ingreso y estudio en cualquiera de las escolanías musicales de la ciudad barcelonesa de la época ${ }^{41}$. Por aquellos años los centros con mayor importancia musical, con capillas musicales y con niños de coro fueron: la catedral — con Josep Pujol (fl. 1735-1779) como maestro de capilla y Francisco Mariner (*Barcelona, 1720; †Ibid, 1789) como organista_; la iglesia de Santa María del Mar, centro del que dependía su familia — contaba con Pedro Antonio Monlleó al cargo del puesto

y en tal concepto se suplica se anuncie en la Gaceta su invalidación. Habana 22 de febrero de 1874. Fermín Pérez" (Pérez, 1874, s.p.).

${ }^{40}$ Documento VI del anexo: $\boldsymbol{E}$-Bc, Llicències d'esposalles, vol. 153. Fol. 130r.

41 También se había anotado en uno de los estudios biográficos del compositor Bruno Pagueras acerca de una hipotética formación en la abadía de Montserrat, dada la vinculación de Bruno Pagueras con Jaume Balius, puesto que del estudio de sus carreras profesionales se pueden establecer diversos enlaces entre ambos (Benavent, 2014). Sirva el presente estudio para desmentirlo y presentar, a tal efecto, nueva documentación, aun siendo, todavía, otra mera hipótesis. 


\section{JOAN BENAVENT PEIRó}

de maestro de capilla_-; el Palacio de la Condesa, al que Bruno Pagueras aspiraría sin éxito años después; la iglesia del Pino y, por último, la iglesia de los Santos Justo y Pastor.

Muy probablemente la formación musical de los hermanos Cayetano y Bruno se llevaría a cabo bajo la regencia de Monlleó en la iglesia de Santa María del Mar, por el hecho de haber pertenecido su familia a la parroquia en cuestión, pero, al menos hasta la fecha, no hay datos para justificarlo ${ }^{42}$. No obstante, hay un dato más que podría acercar la investigación al posible origen musical, al menos de Bruno Pagueras, en la citada escolanía. En 1782 Bruno ejercía el cargo de maestro de capilla de la catedral de Urgel y pedía al obispo Juan García y Montenegro $^{43}$ la ordenación sacerdotal ${ }^{44}$. Por aquel momento, era clérigo tonsurado y en las amonestaciones para su promoción a las cuatro órdenes menores, el obispo enviaba las correspondientes circulares a las iglesias de Vilanova i la Geltrú, donde había ejercido el cargo de organista, pero también a la parroquia de Santa María del Mar, de donde procedía su origen, al menos, familiar ${ }^{45}$. ¿Podría plantearse, acaso, que además de pedir referencias y exponer los votos del licenciado Bruno Pagueras en la misa mayor de la citada parroquia, se aprovechase la cuestión para refrendar la actitud y decoro del entonces maestro de capilla de Urgel? En tal caso, además de pedir referencias a su parroquia de origen, se estaría pidiendo información relacionada con el entorno musical del propio compositor. De momento, pues, no deja de ser una hipótesis el hecho de la posible formación musical de los hermanos Pagueras bajo la tutela de Monlleó.

Además de lo comentado hay otro aspecto que vincula la relación entre los Pagueras y Antonio Monlleó, al menos de Cayetano y su relación con el convento de las Jerónimas, antes visto. Se trata del dato que aporta Xavier Daufí en su estudio sobre la historia del oratorio ${ }^{46}$ en Catalunya durante el siglo XVIII (2004, p. 52). Si bien el apunte no es concluyente, sí anota otro rasgo más que permite establecer el circuito profesional anunciado al inicio del estudio que serviría de modelo laboral a los aquí biografiados.

Han quedado vistos los cargos de organistas que ambos hermanos ejercieron en diferentes parroquias, y no se ha hallado más información sobre la formación musical de los mismos. No obstante, al menos de Bruno Pagueras, se tiene constancia de algunas de las partituras que trabajó como organista, como lo muestran diferentes cuadernos que utilizó

\footnotetext{
${ }^{42} \mathrm{La}$ ausencia de trabajos al respecto y la pérdida de diferentes fondos archivísticos dificultan el proceso de reconstrucción. No podría parecer descabellada la hipótesis que descartara la formación musical de ambos hermanos en la capilla musical de la catedral, puesto que ninguno de los dos músicos aparece en los trabajos referenciales de Josep Pavia sobre la capilla musical de la catedral de Barcelona (Pavia, 2001, 2005).

${ }^{43}$ Juan García de Montenegro (*Lugo, 21.07.1716; †La Seu d’Urgell, 23.05.1783) se licenció en Teología en la Universidad de Ávila y ejerció el cargo de párroco de la iglesia de la Santa Cruz de Madrid antes de ser elegido obispo de Urgel en 1780 (Baraut, Castells, Marquès, \& Moliné, 2002, pp. 101, 102).

44 Documento VIII del anexo: Proclamación a las órdenes menores de Bruno Pagueras Portavella en Barcelona y en Vilanova i la Geltrú. Barcelona, 07.09.1782. E-SU, Órdenes 1780-1782. Caja 863.

45 Documento IX del anexo: Proclama de las cuatro órdenes menores de Bruno Pagueras en la Seu d'Urgell. La Seu d'Urgell, 26.08.1782. E-SU, Órdenes 1780-1782. Caja 863.

${ }^{46}$ Sobre el oratorio véase, entre otros trabajos, el estudio de José Rafael Carreras y Bulbena: El oratorio musical, desde su origen hasta nuestros días (Carreras, 1908); además de los trabajos realizados por Josep Pavia sobre La música en Cataluña en el siglo XVIII. Francesc Valls (1671c-1747) (Pavia, 1997); Daniel Codina: Cataleg dels villancicos i oratoris impresos de la Biblioteca de Montserrat. Segles XVII-XIX (Codina, 2003); y el estudio de Maria Teresa Ferrer Ballester: Antonio Teodoro Ortells (1647-1706): estudio biográfico y estilístico del repertorio musical (Ferrer, 1999).
} 
Nuevos datos Biográficos de Cayetano y Bruno Pagueras.

De Barcelona a La Habana y a La Seu D’Urgell, ResPectivamente

durante sus años de ejercicio del citado cargo. En concreto, se han localizado cuatro cuadernos de órgano, copiados por él mismo, con obras de José Elías y de Francisco Mariner. De las partituras localizadas se conservan diferentes pliegos con obras del primer autor, encuadernados en un mismo volumen del año 1770, cuando Bruno Pagueras todavía era licenciado, en la Biblioteca de Catalunya, en Barcelona. Se trata de diferentes piezas e himnos donde se especifica, de puño y letra del músico, “[...] Codern de Bruno Pagueras ÿ / organista / en Valldonzella / Anÿ 1770 [...]" con referencia explícita al lugar donde ejerció el cargo de organista $^{47}$, previo a su traslado a Vilanova i la Geltrú, que, como se ha comentado, sería, a su vez, el paso previo al de maestro de capilla de la catedral de Urgel. El tercero de los cuadernos copiados y utilizados para solemnizar las funciones litúrgicas también se conserva en la Biblioteca de Catalunya. Se trata del documento que en su portada detalla ${ }^{48}$ : "[...] Psalmodia por todos / los tonos de Mariner / $\mathrm{p}^{\text {re }} / 1771$ / Codern de Bruno Pagueras" pero que en su última página anota el año de 1768 como fecha posible de la conclusión de la copia del manuscrito. Por último, el cuarto pliego es el Rasgo de órgano que hoy se encuentra en el archivo capitular urgelitano, recientemente estudiado y publicado (Ezquerro, 2020).

De los citados documentos se desprende una difusión de los trabajos de José Elías y Francisco Mariner en el uso musical de Bruno Pagueras, no pudiendo, al menos hasta la fecha, aportar nueva información. No obstante, la existencia en los fondos de la misma Biblioteca de Catalunya de otras composiciones organísticas, del entonces escolán de la abadía de Montserrat Francisco Oller ${ }^{49}$, aportan información de interés sobre la difusión de las obras y los trabajos de autores ubicados en Madrid, Montserrat o Barcelona. En su conjunto, podría plantearse que los repertorios habituales de los organistas del momento en la Ciudad Condal contendrían obras, si no de otros compositores, de autores como Anselm Viola, [José o Juan] Moreno [y Polo], Joseph [Antonio] Martí, Narciso Casanovas, Antonio Soler y Joaquín Ojinaga, entre otros ${ }^{50}$.

Si del hermano menor de los Pagueras podría reconstruirse un hipotético entorno musical en sus interpretaciones organísticas, de su hermano Cayetano, en su faceta como organista en el convento de las Jerónimas en su período barcelonés, no se tiene documento alguno que aporte información al respecto, pero podría situársele en idéntico entorno.

Además, el citado alumno de Bruno Pagueras, Francisco Andreví, utilizó, para sus interpretaciones organísticas en los diferentes conventos donde ejerció el cargo, unos cuadernos musicales, algunos hoy conservados en Cervera, con obras de Antón Mestres, Joan Vila, Antonio Coderch, Antonio Soler, José Elías, Narciso Casanovas y Mateo Ferrer (Ballús \& Ezquerro, 2016, p. 77). Si bien es cierto que en los cuadernos del escolán urgelitano

\footnotetext{
$47 \boldsymbol{E}-B b c$, M. 905.

$48 \boldsymbol{E}$-Bbc, M. 906.

49 E-Bbc, M. 847 y M. 848.

${ }^{50}$ La idiomática propia de los instrumentos de teclado en sus diferentes posibilidades organísticas, al pianoforte y al clave, están siendo objeto de estudio, tanto en cuanto a la evolución de la técnica, como en la adaptación de repertorios propios del mundo operístico y sinfónico, ajustados a los instrumentos de tecla, como en la ejemplificación del paso de la modalidad, a la polaridad mayor/menor de la música tonal que fue asentándose a lo largo del siglo XVIII (Yáñez, 2007; Personat, 2012; Yáñez, 2013, 2015; Pallàs, 2017a, 2017b; Benavent, 2019).
} 


\section{JoAn Benavent Peiró}

aparecen autores más propios de su época, todavía en los pliegos en cuestión se encuentran otros compositores que podrían estar ahí presentes por influencia de su maestro. Es por ello por lo que, una vez más, aparecen las influencias musicales en los repertorios para tecla del período con presencia de los autores vistos.

Así pues, del conjunto de composiciones de Bruno Pagueras se advierte un asentamiento y una asimilación de las formas y los géneros musicales que unos años antes habían irrumpido en la península juntamente con la tradición escolástica del ámbito eclesiástico. Las nuevas composiciones muestran las influencias, entre otros, de los géneros reinantes de la cantata, la sonata, el concierto y la sinfonía. Con ello, es en las partituras donde se advierte cómo los compositores, y en concreto Bruno Pagueras, supieron amoldar y adaptar los géneros y los repertorios reinantes en la escena europea dentro de un ámbito eclesiástico, ajustándolos a las formas propias del templo. De hecho, la producción pagueriana refleja ambos mundos, al menos en el caso de Bruno Pagueras. Por una parte, su producción litúrgica mantiene, en su mayoría, una escritura propia de los cánones escolásticos, con composiciones a dos coros con acompañamiento de bajo continuo a cargo del bajón y, en otros casos, con piezas — tales como misas, lamentaciones, misereres, etc.que contienen un reparto instrumental con todos instrumentos, esto es, con oboes o flautas, violines y trompas — bien entendida como la orquesta propia de la época preclásica, y aun del primer clasicismo- . Por otro lado, y ya en el otro extremo del estilo musical, más al día de las corrientes musicales influenciadas por la irradiación de la ópera, sus villancicos contemplan una estructura de piezas con introducción, recitados y arias, ya propios del mundo operístico.

\section{CONCLUSIONES}

Los nuevos datos de archivo transcritos en el anexo final de la investigación permiten reconstruir una parte del árbol genealógico de la familia Pagueras Portavella, aportando información de interés para el estudio de la historiografía musical y los lazos de unión entre la península y los territorios de ultramar. Pero, a su vez, de la correlación establecida entre los datos sacados de los archivos consultados y las partituras conservadas, puede delimitarse un circuito de ascenso y de promoción laboral, que permite reconstruir los pasos de ascenso de cualquier músico que optase a una carrera profesional y que pretendiese, por tanto, hacerse un hueco en el panorama musical del momento. Así pues, de la propuesta vista de los hermanos Pagueras y de la trayectoria de dos de los alumnos de Bruno en La Seu d'Urgell, podría establecerse un circuito de ascenso laboral entre la formación musical en una capilla catedralicia y el acceso a cargos de mayor rango, primero como intérpretes, en el caso aquí tratado como organistas, y después como maestros de capilla. Y, en el caso de una élite de jóvenes músicos salidos de las capillas musicales, si la suerte y el talento estaban de su parte, sus futuras carreras podrían permitirles el acceso a los puestos mejor valorados del panorama musical, tales como catedrales de circunscripción metropolitana o, incluso, en la Real Capilla. 
Nuevos datos biográficos de Cayetano y Bruno Pagueras. DE BARCElona A LA HABANA Y A LA SEU D'URGELL, RESPECTIVAMENTE

En el caso de los hermanos Pagueras, después de su supuesta formación musical bajo la tutela de Monlleó en la capilla musical de Santa María del Mar, ambos pasarían a ejercer el cargo de organistas de dos centros diferentes. El convento de las Jerónimas, para el caso de Cayetano - y cabe recordar la presencia del oratorio de Monlleó en dicho convento-, y el de la Valldonzella, para su hermano Bruno. En el caso del hermano menor, el cargo le serviría, a su vez, para acceder a Vilanova de Cuberes, que le lanzaría, finalmente, al puesto de maestro de capilla de la catedral de Urgel. En cambio, su hermano mayor, del puesto de organista conventual pasaría al cargo de organista de la catedral de La Habana y de contralto de la capilla musical de la misma entidad, además de mantener relación laboral con otros centros isleños, ejerciendo el cargo de organista del convento de los belemitas entre $1795 \mathrm{y}$ 1805, como detallaba Pearce (2016, p. 36). Dichos puestos, entre otros, le servirían para establecer contactos profesionales con la catedral de Puebla en México, llegando, al parecer por méritos propios y por la recomendación del obispo Biempica, a ocupar, según parece, de manera cuando menos nominal, el cargo de maestro de capilla de la catedral de Puebla de los Ángeles. Podría afirmarse, incluso, que la experiencia adquirida a lo largo de los años en Barcelona, tanto como intérprete como compositor, le serviría a Cayetano de salvoconducto, o, como mínimo, de carta de presentación, para su mejor acomodo en suelo cubano y mexicano.

Todavía hoy, la figura de Cayetano Pagueras merece replantear, aún más, su trayectoria, dado el interés que tuvo en su época y la recepción que tuvo su obra, según la valoración de Francisco de Asís Martínez. Por otra parte, la opinión que se formó de su persona, a partir de los detractores que difamarían su buen nombre y reputación, merecen, como anotaban Franco Gutiérrez y Miriam Escudero, dicho replanteamiento. En este sentido, cabe recordar la compra de partituras que el futuro maestro de la catedral habanera, Manuel Lazo de Vega, le hacía al mismo Cayetano, y las vilipendiarias afirmaciones que sobre él vertería Juan Nepomuceno Goetz. Aspectos que dejan la duda abierta sobre cómo sería el trato recibido por el compositor para que tomase cartas en el asunto dejando Veracruz y retornando a La Habana.

Volviendo al caso barcelonés, en ambos casos, tanto para Cayetano como para Bruno, el hecho de poder empezar una carrera como organistas en centros pequeños les permitiría mejorar sus cualidades interpretativas y, a su vez, tomar el pulso a las novedades musicales del momento. Cabe recordar que la Ciudad Condal era un centro bullicioso en representaciones teatrales, música litúrgica y en academias, con la presencia de autores y géneros procedentes del resto del Europa.

La trayectoria laboral de ambos hermanos sería, a grandes rasgos, la que continuarían los alumnos de Bruno Pagueras, formados en la capilla musical de la catedral de Urgel, perpetuando el modelo de ascenso laboral y de carrera profesional antes mencionado. Pero la diferencia entre la generación de los Pagueras y la de los escolanes urgelenses Francisco Andreví y Ramón Carnicer estribaría en que ambos escolanes llegarían a alcanzar mayor proyección, formando parte de la élite musical española a lo largo del siglo de las revoluciones liberales, promocionándose, a su debido tiempo, para ocupar cargos de primerísimo orden dentro del panorama musical del momento. 


\section{JoAn Benavent Peiró}

En el caso de Andreví, después de su formación en la capital de l'Alt Urgell se le enviaría a Barcelona, al parecer por gestiones del propio cabildo, para continuar sus estudios con Juan Quintana y Francisco Queralt. El hecho de poder ampliar sus estudios en Barcelona le valdría para empezar a ejercer su carrera en la misma Ciudad Condal y como organista de diferentes conventos, siguiendo los pasos de su profesor Bruno Pagueras. Con el tiempo, el músico de Sanaüja adquiriría la merecidísima suficiencia técnica e interpretativa para ganar a tantos contendientes como se le presentaran. A lo largo de su carrera, Andreví desarrolló su actividad como maestro de capilla en Segorbe, Santa María del Mar en Barcelona, en las catedrales metropolitanas de Valencia y Sevilla, en la Real Capilla o, en sus últimos años, en la iglesia de la Mercè en Barcelona, además del magisterio de la catedral de Burdeos y el puesto de organista en la iglesia de Saint Pierre de Chaillot en París.

En cuanto a Ramón Carnicer, su periplo profesional también seguiría los pasos de su maestro urgelense, a la vez que desarrollaría una carrera similar a la de su condiscípulo y amigo Andreví, con quien llegaría a coincidir, ambos como profesores, en el Conservatorio de Madrid. En su caso, después de la formación pirenaica, llegaría, también como el anterior, a Barcelona para estudiar con el maestro de la catedral Francisco Queralt y con el organista Carlos Baguer. Pero, a diferencia del de Sanaüja, el de Tárrega mantendría una estrecha relación con el Teatre de la Santa Creu de Barcelona, centro insigne de la ópera italiana, del que llegaría a ser director, en un puesto que le favorecería para su posterior vinculación con los teatros de la corte en Madrid.

En conclusión, el hallazgo documental de la ascendencia familiar de Cayetano y Bruno ha servido para poder ver, con perspectiva, la carrera musical de ambos, dentro de su contexto, a la vez que ha permitido valorar el cargo de organista conventual barcelonés a mediados del siglo XVIII. Puesto que les permitió adquirir oficio, a la par que les favorecería poder asistir a las representaciones y funciones musicales de todo tipo - camerísticas, litúrgicas, operísticas y de música sinfónica- que se llevarían a cabo en las conocidas academias barcelonesas, en el Teatre de la Santa Creu o en los diferentes centros de culto de la Ciudad Condal. Después de todo, un modelo de promoción laboral que se perpetuaría en la generación posterior con los preveners urgelenses, alumnos de Bruno Pagueras, Francisco Andreví y Ramón Carnicer. Además, la lectura de la bibliografía publicada sobre Cayetano Pagueras con un punto de vista "crítico", abre el debate para replantear su figura. En este sentido, la nueva mirada merecería documentar, con nuevas fuentes de archivo y otros enfoques, su acceso al cargo de maestro de capilla, aunque breve, de la catedral angelopolitana, previo al acceso de Manuel Areanza. Y, por si no fuera poco, también merecería aportar nuevos enfoques del paso efímero que dicho maestro tuvo en la capilla de la catedral habanera, como maestro de capilla "interino", en un momento puntual del magisterio de Juan Nepomuceno Goetz. 
Nuevos datos biográficos de CAYetano y Bruno Pagueras.

De Barcelona a La Habana y a La SEU D’URgell, RESPECTIVAMENTE
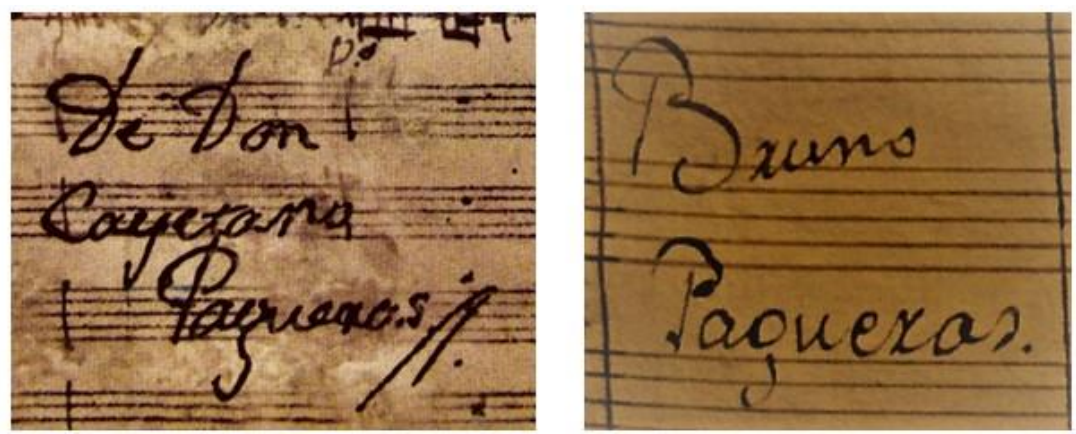

Fig. 5: Firmas de los hermanos Pagueras Portavella, sacadas, respectivamente, de Escudero Suástegui, 2013b51 y del archivo $\boldsymbol{E}$-SUe, 1667.05.

\section{BIBLIOGRAFÍA}

Álvarez Cañíbano, A. (2014). Músicas para tiempos convulsos. Revista de Musicología, 37(1), pp. 353-355.

Alcalde Vilà, S. (2017). Què sabem dels orgues de Canet? Un intent de recopilació de dades sobre els orgues i organistes de Canet (1a part). El Sot de l'Aubó, 62, pp. 3-9. Disponible en: https://www.raco.cat/index.php/SotAubo/article/view/331041 [fecha de consulta: 01.08 .2020$]$.

Amades i Gelat, J. (1984). Històries i llegendes de Barcelona. 2 vols. Barcelona: Edicions 62.

Baldelló Benosa, F. (1962). La música en la basílica parroquial de Santa María del Mar, en Barcelona: Notas históricas. Anuario Musical, 17, pp. 209-241.

Ballús Casóliva, G. (2004). La música a la col-legiata basílica de Santa Maria de la Seu de Manresa, 1714-1808. Dades documentals per a la seva reconstrucció amb una aproximació al repertori litúrgic conservat. (Tesis Doctoral). Barcelona: Universitat Autònoma de Barcelona, Departament d'Art. Facultat de Filosofia i Lletres.

Ballús Casóliva, G. (2009). La música a Manresa entre els segles XVII i XVIII. En M. Torras (Ed.), Manresa. De la guerra dels Segadors a la Guerra Gran (pp. 259-296). Manresa: Centre d'Estudis del Bages i Ajuntament de Manresa.

\footnotetext{
${ }^{51}$ La imagen de la firma de Cayetano se ha extraído del volumen de Escudero Música catedralicia de Cuba. Repertorio litúrgico de Cayetano Pagueras (Barcelona - La Habana, siglos XV III y XIX) publicado por el Gabinete de Patrimonio Musical Esteban Salas de La Habana (Escudero, 2013b).
} 


\section{JoAn Benavent Peiró}

Ballús Casóliva, G. \& Ezquerro Esteban, A. (2016). Música en imágenes. Francisco Andreví (*1786; +1853), músico de iglesia y compositor cosmopolita en un mundo cambiante. Madrid: Alpuerto.

Ballús Casóliva, G. \& Ezquerro Esteban, A. (2019a). Francisco Andreví (*1786;†1853) entre Francia y España: composición musical e implicaciones sociales en la primera mitad del siglo XIX. Parte 1. Una trayectoria en ascenso: del Pirineo hacia el sur. Desde la Seu d’Urgell a la Real Capilla. Cuadernos de Investigación Musical, (7), pp. 3-48. Disponible en:

https://revista.uclm.es/index.php/cuadernosdeinvestigacionmusical/article/view/19 91 [fecha de consulta: 10.09.2020].

allús Casóliva, G. \& Ezquerro Esteban, A. (2019b). Francisco Andreví (*1786; †1853) entre Francia y España: composición musical e implicaciones sociales en la primera mitad del siglo XIX. Parte 2. A ambos lados Pirineo. Burdeos, París y Barcelona. Cuadernos de Investigación Musical, (8), pp. 77-114. Disponible en: https://revista.uclm.es/index.php/cuadernosdeinvestigacionmusical/article/view/20 95 [fecha de consulta: 10.09.2020].

Baraut Obiols, C., Castells Serra, J., Marquès Sala, B. \& Moliné Coll, E. (2002). Episcopologi de l'Església d'Urgell. La Seu d'Urgell: Societat Cultural Urgel·litana.

Bedmar Estrada, L. P. (2009). La música en la catedral de Córdoba a través del magisterio de Jaime Balius y Vila. Córdoba: Junta de Andalucía, Consejería de Cultura.

Benavent Peiró, J. (2014). Apuntes biográficos del maestro de capilla de la Seu d’Urgell Bruno Pagueras. En R. Marreco \& M. A. Brescia (Ed.). Actas do II Encontro Iberoamericano de Jovens Musicologos (Oporto, 26-27 de febrero de 2014) (pp. 309-314). Porto: CESEM / TagusAtlanticus Associação Cultural.

Benavent Peiró, J. (2018). La actividad musical en la catedral de la Seu d’Urgell en 1781-1801, a partir del ms. 890 del Llevador de la obra. Cuadernos de Investigación Musical, (6), pp. 195240.

Disponible en: https://revista.uclm.es/index.php/cuadernosdeinvestigacionmusical/article/view/19 45 [fecha de consulta: 05.09.2020]. 


\section{Nuevos datos biográficos de CAYETANO Y BRUno Pagueras. DE BARCElona A LA HABANA Y A LA SEU D'URGELL, RESPECTIVAMENTE}

Benavent Peiró, J. (2019). El periòdic musical de Maria Rosa d'Areny i Jordana de la Casa Museu d'Areny Plandolit d'Andorra. Papers de recerca històrica (Del Consell de la Terra al Consell General, 600 anys d'bistòria), 9, pp. 151-188. Disponible en: https://publicacions.iec.cat/repository/pdf/00000285/00000100.pdf [fecha de consulta: 07.06.2020].

Benavent Peiró, J. (2020). The first record from Andorra in RISM: The periodico de musica of Maria Rosa d'Areny Jordana. Disponible en: : http://www.rism.info/en/home/newsdetails/select/self_representation/article/64/ the-first-record-from-andorra-in-rism-the-periodico-de-musica-of-maria-rosa-darenyjordana.html [fecha de consulta: 07.08.2020].

Bermúdez Cujar, E. (2014). Domenico Zipoli. Para una genealogía de la música clásica latinoamericana. Premio de musicología Casa de las américas 2003. Revista de Musicología, 37(1), pp. 218-228.

Bimberg, G. (1993). El trasvase musical hispano-cubano en el siglo XVIII. Revista de Musicologia, 16(5), pp. 2835-2841.

Bonastre Bertran, F., Gregori Cifré, J. M. \& Guinart Verdaguer, A. (2009). Inventaris dels Fons Musicals de Catalunya, Volum 2/1 - 2/2: Fons de la Parròquia de Sant Pere i Sant Pau de Canet de Mar. Barcelona: Universitat Autònoma de Barcelona - Departament de Cultura i Mitjans de Comunicació de la Generalitat de Catalunya.

Cabot Sagrera, N. \& Gregori Cifré, J. M. (2010). Inventaris dels Fons Musicals de Catalunya, Volum 4: Fons del Museu-Arxiu de Santa Maria de Mataró. Barcelona: Universitat Autònoma de Barcelona - Departament de Cultura i Mitjans de Comunicació de la Generalitat de Catalunya.

Carpentier, A. (1946). V. Una conjura en la catedral de La Habana. En A. Carpentier La música en Cuba (pp. 132-141). México: Fondo de Cultura Económica, Colección popular.

Carreras Bulbena, J. R. (1908). El oratorio musical, desde su origen hasta nuestros días. Barcelona: L'Avenç.

Codina i Giol, D. (2003). Catàleg dels villancicos i oratoris impresos de la Biblioteca de Montserrat. Segles XVII-XIX. Montserrat: Publicacions de l'Abadia de Montserrat, Scripta et Documenta, 64. 


\section{JoAn Benavent Peiró}

Civil Castellví, F. (1968). La capilla de música de la catedral de Gerona (siglo XVIII). Anals de l'Institut d'Estudis Gironins, 19, pp. 131-188.

Daufí Rodergas, X. (2004). Els oratoris de Francesc Queralt (1740-1825). Història de l'oratori a Catalunya al segle XVIII. Lleida: Diputació de Lleida i Institut d'Estudis Ilerdencs.

Díaz Cayeros, P. (2007). Un inventario de 1749 y el examen de oposición de Joseph Lazo y Valero. Documentos inéditos de la Catedral de Puebla. Cuadernos del Seminario Nacional de Música en la Nueva España y el Nuevo México Independiente, 2, pp. 32-40.

Dumás Chancel, M. (1868). Guía del profesorado cubano para 1868. Anuario de pedagogía y estadística de la enseñanza. Matanzas: Imprenta el ferrocarril.

Enríquez Rubio, L., Davies, D. E. \& Cherñavsky, A. (2014). Catálogo de obras de Música del Archivo del Cabildo Catedral Metropolitano de México. Volumen I. Villancicos y cantadas. México: Universidad Nacional Autónoma de México, Instituto de Investigaciones Estéticas.

Enríquez Rubio, L., Davies, D. E. \& Cherñavsky, A. (2015). Catálogo de obras de Música del Archivo del Cabildo Catedral Metropolitano de México. Volumen II. Visperas, antífonas, salmos, cánticos y versos instrumentales. México: Universidad Nacional Autónoma de México, Instituto de Investigaciones Estéticas.

Escudero Suástegui, M. (1998). El archivo de música de la iglesia habanera de la Merced. Estudio y catálogo. La Habana (Cuba): Fondo editorial Casa de las Américas.

Escudero Suástegui, M. (2012). Esteban Salas (La Habana, 1725-Santiago de Cuba, 1803). En M. Escudero (Dir.). Músicos de la Catedral de Santiago de Cuba siglos XVI-XIX (pp. 45182). Santiago de Cuba: Ediciones Caserón.

Escudero Suástegui, M. (2013a). Cayetano Pagueras y la Capilla de música de la catedral de la Habana, repertorio litúrgico, vol. 9. La Habana y Valladolid: Oficina del Historiador de la ciudad de la Habana. Centro de investigación y desarrollo de la música cubana. Universidad de Valladolid (España).

Escudero Suástegui, M. (2013b). Música catedralicia en Cuba. Repertorio litúrgico de Cayetano Pagueras (Barcelona-La Habana, siglos XVIII y XIX) [CD + DVD]. (Colibrí - La Ceiba, Ed.). La Habana: Gabinete de Patrimonio Musical Esteban Salas.

Escudero Suástegui, M. (2015). Cayetano Pagueras, entre iglesias y catedrales de Cuba y México (1778-1814). Revista Clave, CIDMUC, 17(1), pp. 5-11. 


\section{Nuevos datos biográficos de CAYETANo y BRUno Pagueras. DE BARCElona A LA HABANA Y A LA SEU D'URGELL, RESPECTIVAMENTE}

Escudero Suástegui, M. (2016). Documentos sonoros del patrimonio musical cubano, Cayetano Pagueras y la capilla de música de la catedral de la Habana, siglo XVIII. Anales de la Academia de Ciencia de Cuba, 6(3). Disponible en: http://www.revistaccuba.cu/index.php/revacc/article/view/597/604 [fecha de consulta: 18.10 .2020$]$.

Ester-Sala, M. \& Vilar Torrens, J. M. (1987). Una aproximació als fons manuscrits musicals de Catalunya [1]. Anuario Musical, 42, pp. 229-243.

Ester-Sala, M. \& Vilar Torrens, J. M. (1989). Una aproximació als fons manuscrits musicals de Catalunya II. Anuario Musical, 44, pp. 155-166.

Ester-Sala, M. \& Vilar Torrens, J. M. (1991). Una aproximació als fons manuscrits musicals de Catalunya III. Anuario Musical, 46, pp. 295-320.

Ezquerro Esteban, A. (2020). Elogio de la disonancia en el barroco hispánico, y del concepto de licencia. De las teorías en «el porqué de la música» a un «rasgo de órgano» sobre un intento cromático de Elías. En A. Krutitskaya (Ed.). Celebración y sonoridad en Hispanoamérica (siglos XVI-XIX) (pp. 136-234). Ciudad de México: Universidad Nacional Autónoma de México.

Fallarero Valdivia, C. (2012). Juan París (Cataluña, ca. 1759-Santiago de Cuba, 1845). En M. Escudero (Dir.). Músicos de la Catedral de Santiago de Cuba siglos XVI-XIX (pp. 183-218). Santiago de Cuba: Ediciones Caserón.

Ferrer Ballester, M. T. (1999). Antonio Teodoro Ortells (1647-1706). Estudio biográfico y estilistico del repertorio musical. (Tesis Doctoral). Valladolid: Universidad de Valladolid.

Franco Gutiérrez, M. D. (2019). Manuel Arenzana (*1750; \$1821) el último maestro de capilla novohispano en la catedral de Puebla. Edición crítica de Los Maitines a la Purísima Concepción (1794-1797). Ciudad de México: Universidad Nacional Autónoma de México.

Fuentes Matons, L. (1981). Las artes en Santiago de Cuba. Ciudad de La Habana: Editorial Letras Cubanas.

Galí Boadella, M. (2007). Ritual y música en las honras fúnebres de los obispos poblanos. En P. Díaz (Ed.). Seminario Nacional de Música en la Nueva España y el México Independiente. 2. Coloquio Musicat. Lo sonoro en el ritual catedralicio: Iberoamérica, siglos XVI-XIX (pp. 43-58). Guadalajara, Jalisco: Editorial Gráfica Nueva de Occidente. 


\section{JoAn Benavent Peiró}

Galí Boadella, M. (2017). El arte en el momento de la consagración de los tabernáculos de la catedral de Puebla (1649 y 1819). Consideraciones sobre arte y liturgia. En L. Enríquez (Ed.). De música y cultura en la Nueva España y el México independiente: Testimonios de innovación y pervivencia. Volumen II (pp. 161-184). México: Instituto de Investigaciones Estéticas de la Universidad Nacional Autónoma de México.

González Ruiz, M. (2007). Els orgues de les comarques de Lleida i Andorra. Lleida: Pagès.

Gregori Cifré, J. M. (2009). Tomàs Milans (1672-1742) i el fons musical de Sant Pere i Sant Pau de Canet. El Sot de l'Aubó, 30, pp. 18-23.

Gregori Cifré, J. M. (2012). Fons musicals del Maresme (I): Església parroquial de Sant Pere i Sant Pau de Canet de Mar. Singladures. Revista de cultura, història i patrimoni de Vilassar de Mar i el Maresme, 30, pp. 57-94.

Gregori Cifré, J. M. (2020). Francesc Bonastre (1944-2017), artífex de la recuperació del fons musical de Canet de Mar. El Sot de l'Aubó, XVIII, 71, pp. 3-6.

Gregori Cifré, J. M. \& Romeu Solà, A. (2016). Inventaris dels fons musicals de Catalunya. Volum 9, Fons de la basilica de Santa Maria d'Igualada de l'Arxiu Comarcal de l'Anoia. Barcelona: Universitat Autònoma de Barcelona.

Guerberof Hahn, L. (2007). El archivo de música de la insignie y nacional Basílica de Santa María de Guadalupe de México. Anuario Musical, 62, pp. 257-270.

Hernández Balaguer, P. (1964). La capilla de música de la catedral de Santiago de Cuba. Revista Musical Chilena, 18(90), pp. 14-61.

Jiménez Cavallé, P. (1998). Documentario musical de la catedral de Jaén, vol. II. Granada: Centro de Documentación Musical de Andalucía.

Koegel, J. (2000). Lazo [Lasso, Laso], Valero, José Joaquín. En Diccionario de la Música Española e Hispanoamericana, vol. 6 (p. 824). Madrid: Sociedad General de Autores y Editores.

Lazos, J. G. (2015). Entre catedrales y parroquias, un fragmento olvidado de la memoria sonora en el México del siglo XIX. Resonancias, Revista de investigación musical, 37, pp. 135157.

Llorens Cisteró, J. M. (2000). Monlleó, Pedro Antonio. En Diccionario de la Música Española e Hispanoamericana, vol. 7 (p. 696). Madrid: Sociedad General de Autores y Editores. 
Nuevos datos biográficos de Cayetano y Bruno Pagueras. De Barcelona a La Habana y a La Seu D’Urgell, ResPectivamente

Llorens Cisteró, J. M. (2001). Pagueras [Paqueras], Bruno. En Diccionario de la Música Española e Hispanoamericana, vol. 8 (p. 353). Madrid: Sociedad General de Autores y Editores.

Lorenzino, L. (2013). Esteban Salas and his legacy of music education in Cuba. Journal of Historical Research in Music Education, 34 (2), pp. 101-118.

Maní Andrade, A., Franco Gutiérrez, M. D. \& Tello Malpartida, A. (2015). Proyecto de catalogación, transcripción, investigación y difusión del archivo musical del venerable cabildo de la catedral de Puebla. Catálogo y apéndice biográfico de compositores novohispanos. Ciudad de México: Consejo Nacional para la Cultura y las Artes. Instituto Nacional de Bellas Artes. Consejo Estatal para la Cultura y las Bellas Artes de Puebla.

Marín-López, J. (2007). Consideraciones sobre la trayectoria profesional del músico Antonio Juanas (1762/63 - después de 1816). Cuadernos del Seminario Nacional de Música en la Nueva España y el México Independiente, 2, pp. 14-31.

Mas Gibert, X. (2004). L'arxiu musical de Canet de Mar. El Sot de l'Aubó, 10, pp. 26-28.

Mas Gibert, X. \& Saiz Xiqués, C. (2009). La capella de Música de l'església de Sant Pere i Sant Pau: La catedral de la Costa dels segles XVII i XVIII. El Sot de l'Aubó, 30, pp. 3-17.

Pallàs Mariani, L. (2017a). Estudi codicologic i catalogació del manuscrit E-VI-293, vol. 1. (Tesis doctoral). Barcelona: Universitat Autònoma de Barcelona.

Pallàs Mariani, L. (2017b). Estudi codicològic i catalogació del manuscrit E-VI-293, vol. 2. (Tesis doctoral). Barcelona: Universitat Autònoma de Barcelona.

Pavia Simó, J. (1997). La música en Cataluña en el siglo XVIII. Francesc Valls (1671c-1747). Barcelona: CSIC, Monumentos de la Música Española, 53.

Pavia Simó, J. (2001). La capella de música de la Seu de Barcelona des de la mort del mestre Francesc Valls (2-6-1747) fins a l’any 1755. Anuario Musical, 56, pp. 131-162.

Pavia Simó, J. (2005). La capella de música de la Seu de Barcelona en el segle XVIII (17561765). Anuario Musical, 60, pp. 71-113.

Pareyón, G. (2007). Arenzana, Manuel de. En Diccionario Enciclopédico de Música en México, 2 volúmenes. Guadalajara, México: Universidad Panamericana.

Pareyón, G. (2007). Cruzelaegui, (fray) Martín (Francisco) de. En Diccionario Enciclopédico de Música en México, 2 volúmenes. Guadalajara, México: Universidad Panamericana. 


\section{JoAn Benavent Peiró}

Pearce Pérez, M. C. (2016). La actividad musical en los espacios religiosos de la Habana en la segunda mitad del siglo XIX. (Trabajo Fin de Máster). Oviedo, Granada: Universidades de Oviedo, Universidad de Granada y Universidad Internacional de Andalucía.

Pérez, F. (1874). [Sin título]. Gaceta de La Habana, (52-76).

Pérez Martínez, A. J. (1804). Oración fúnebre del Ilustrísimo señor D. Salvador Biempica y Sotomayor caballero profesor de la orden de Calatrava, obispo de Puebla de los Ángeles del Consejo de S. M. [...]. Madrid: Imprenta de la viuda Ibarra con licencia.

Personat Remolar, A. (2012). Metodología analítica comparada de procedimientos compositivos y estilísticos en el periodo ilustrado hispánico: música de tecla inédita en Villarreal (Castellón). Manuel Ciurana, Juan Moreno y Polo, José Ferrer, et al. (Tesis doctoral). València: Universitat Politècnica de València.

Pujol Tubau, P. (1984). Obra completa de Pere Pujol Tubau, arxiver de la catedral d'Urgell. Andorra la Vella: Editorial Andorra.

Rifé Santaló, J. (2001). Monlleó, Pere Antoni. En Gran Enciclopèdia de la Música, vol. 5. Barcelona: Enciclopèdia Catalana.

Rodríguez, V. E. (2004). Sinfonía a la cubana. Kubanische kunstmusik. En T. Eßer \& P. Frölicher (Ed.), Alles in meinem Dasein ist Musik [...]. Kubanische Musik von Rumba bis Techno (pp. 379-403). Fráncfort del Meno: Vervuert.

Roig Capdevila, J. (2004). Presencia musical en la catedral de la Seu d'Urgell en la segunda mitad del siglo XVIII a través de sus actas capitulares. Anuario Musical, 59, pp. 115-150.

Sáenz Coopat, C. M. (2001). Pagueras, Cayetano. En Diccionario de la Música Española e Hispanoamericana, vol. 8 (p. 353). Madrid: Sociedad General de Autores y Editores.

Salazar Andreu, J. P. (2005). Algunos aspectos políticos y jurídicos del obispo de Puebla Salvador Biempica y Sotomayor 1790-1802. Anuario Mexicano de Historia del Derecho. 17, pp. 83-96.

Saldoni Remendo, B. (1881). Diccionario biográfico-bibliográfico de efemérides de músicos espanyoles, vol. IV. Madrid: Imprenta a cargo de D. Antonio Pérez Dubrull.

Salicrú Puig, M. (1995). Manual dels vicaris (VIII). Fulls del Musen Arxiu de Santa Maria, 51, pp. 39-41. 
Nuevos datos biográficos de Cayetano y Bruno Pagueras.

DE BARCElona A LA HABANA Y A LA SEU D'URGELL, RESPECTIVAMENTE

Soriano-Fuertes y Piqueras, M. (1855). Historia de la música española desde la venida de los fenicios hasta el año de 1850, vol. IV. Madrid: Narciso Ramírez.

Stanford, T. (2002). Catálogo de los acervos musicales de las catedrales metropolitanas de México y Puebla de la Biblioteca Nacional de Antropología e Historia y otras colecciones menores. México, D. F.: Colección Historia.

Stevenson, R. M. (1978). Sixteenth-through eighteenth-century resources in Mexico: Part III. Fontes Artis Musicae, 25(2), pp. 156 - 187.

Yáñez Navarro, C. (2007). Música para pianoforte, órgano y clave, en dos cuadernos zaragozanos de la primera mitad del siglo XIX. Anuario Musical, 62, pp. 291-394.

Yáñez Navarro, C. (2013). Piezas para clave, órgano y piano en dos cuadernos misceláneos españoles del siglo XIX. Madrid: Consejo Superior de Investigaciones Científicas.

Yáñez Navarro, C. (2015). Nuevas aportaciones para el estudio de las sonatas de Domenico Scarlatti: los manuscritos del Archivo de música de las catedrales de Zaragoza. (Tesis doctoral). Barcelona: Universitat Autònoma de Barcelona. Departament d'Història de l'Art i Musicologia. 
APÉNDICE ${ }^{52}$

I. Demanda matrimonial entre Lorenzo Pagueras y Catarina Portavella AL obisPado de BARCELONA, 30.08.1746. E-BC, LLICÈNCIES D'ESPOSALLES, VOL. 136. FOL. 19R.

“[...] Die 30. De Agost 1746 [...] Dit Die [en el margen izquierdo] Paguera. [centrado] Llorens Paguera Criat natural de St Julia, de Vall Fogona Bt de Vich ab Catharina Portavella Da [doncella] Pa [parroquia] Sta Maria del Mar... $£$ $8 \phi "$.
“[...] Dia 30 de agosto 1746 [...] Dicho día [en el margen izquierdo:] Paguera[s]. [Centrado:] Llorens Paguera[s] criado [de oficio] natural de Sant Julià, de Vall Fogona obispado de Vic [actual provincia de Girona] con Catharina Portavella doncella parroquia [de] Santa María del Mar [de Barcelona]... $£ 8 \phi "$.

II. Matrimonio entre Lorenzo Pagueras y Catarina Portavella. Barcelona, Santa María del Mar, 30.08.1746. E-Bad. Archivo Parroquial de Santa María DEL MAR. EXPEDIENTES MATRIMONIALES DE 1746. Ms. 151.

[fol. 1r., publicación de las amonestaciones matrimoniales. Barcelona, 28.08.1746:] "Mediant la gracia del Esperit Sant Matrimoni se ha / tractat entre Llorens Pagueras criat natural de Sant Julià de Vall / fogona [del Ripollès, hoy Girona] Bisbat de Vich fill de Diego Pagueras Brasser, vivint, y / de Rosa Casasas conjs [cónyuges] de una part $\mathrm{Ab}$ Catherina Portavella don, / zella natural de St. Cicilia [Santa Cecília de Voltregà?, hoy Girona] de Vich filla de Geroni / Portavella difunt, y de Franca Portavella vivint habitan[t] dits contra/ hents de esta part de molts anys en la present Parroquia de Santa / Maria del Mar.

Supra dicti contrahentes fuerunt publicati in ecclessia parli Beata / Maria de mari, tribus diebus festivis continuis, inter myssarum solem / nia, juxta disponem S. C. T. [el Santo Concilio Tridentino] et nullum apparuit impedimentum; de / quo, et de fidei idoneitate; tam viri per duos [fol. 1r., publicación de les amonestaciones matrimoniales. Barcelona, 28.08.1746:] "Mediante la gracia del Espíritu Santo Matrimonio se ha tratado entre Llorens Pagueras criado natural de Sant Julià de Vallfogona [del Ripollés, hoy Girona] obispado de Vic hijo de Diego Pagueras Brasse, viviente, y de Rosa Casasas cónyugues de una parte con Catherina Portavella doncella natural de Santa Cecilia [¿de Voltregà, Girona?] de Vic hija de Geroni Portavella difunto, y de Francisca Portavella viviente habitantes dichos contrayentes de esta parte de muchos años en la presente parroquia de Santa María del Mar.

Estos contrayentes dichos más arriba fueron publicados en la iglesia parroquial de Santa María del Mar, en tres días festivos continuos, durante las misas solemnes, según dispone el Santo Concilio Tridentino, y no ha aparecido ningún impedimento. De lo cual, y de la

\footnotetext{
52 Se incluyen los materiales de archivo trabajados a lo largo del estudio y se incorporan en transcripción diplomática, en la columna de la izquierda, y en su traducción actual normalizada, en la de la derecha, normalizando las abreviaturas e incorporando información complementaria entre corchetes, diferenciando así el material originario del añadido por el investigador.
} 
Nuevos datos biográficos de Cayetano y BRUno Pagueras.

DE BARCELONA A LA HABANA Y A LA SEU D'URGELL, RESPECTIVAMENTE

annos, quam domicelle habitantes / per annos quinque; in hoc civitate, et nunch in hac parochia con- / morantium fidem facio Barne., die 28 augusti 1746.

De quo fidem facit presbiter, et curator dictte Ecclessie.

[fol. 1v., licencias para la celebración del matrimonio:] Se rebra info los dos contrahens / Vila V. G.

Licenciam quem concedimus Parrocho re- / tro scripto assistendi matrimonio celebrando inter contrahentes / in transriptus monitionibus principaliter nominatos servata for- / ma etc. et uin culto ///. Barn ${ }^{\text {ne }}$ die 29 Augusti 1746. / Vila i Campa, V[icario] G[eneral] O[ficial]. / Copiada / Pro Dre Antonio Campillo pbrõ notõ / Dr. Joan Bta Graciós pbr Esã [escriba de] letra. [Inscripción al matrimonio:] Dicto Die Solvit Ius tabule /Opê $\hat{5}^{3}$ Petrus Martí pr. / Als 30 de Agost de 1746 / yo lo infraescrit ê ass/ istit al matrimoni / celebrat entre los resto / escrits contrahents foren / testimonis Bonaventura $\mathrm{Ba}$ / lasch negociant, y Miguel / Rossinyol Negociant. / D $\underline{\underline{r}}$ Pere Moles Pre Curat de Sta Maria del Mar.". idoneidad de cuya fe, tanto el varón, con residencia de dos años en esta ciudad y parroquia, como la doncella, con residencia de cinco años en la misma, doy fe ahora en esta parroquia en Barcelona, el día 28 de agosto de 1746.

De lo que da fe el sacerdote y cura y párroco de esta iglesia.

[fol. 1v., licencias para la celebración del matrimonio:] Se recibirá información de los contrayentes. [Rubrica:] Vila vicario general.

Licencia que concedemos al párroco antes escrito, para que asista y celebre el matrimonio entre los contrayentes, especialmente nombrados en la copia de las amonestaciones, observada la forma etc. y uso de la iglesia. Dadas en Barcelona el día 29 de agosto de 1746. [Rubrica:] Vila i Campa, Vicario General y Oficial. Copiada [Rubricada:] Por el Doctor Antonio Campillo presbítero notario y Dr. Joan Bautista Graciós presbítero escribano de letra. [Inscripción al matrimonio:] Dicho día se pagaron los derechos de mesa a Pedro Martí cura. A 30 de agosto de 1746, yo el infrascrito he asistido al matrimonio celebrado entre los sobre escritos contrayentes; fueron testigos. Bonaventura Balasch negociante, y Miguel Rossinyol Negociante. Doctor Pere Moles cura párroco de Santa María del Mar."

\section{Bautismo de Isidro Lorenzo José [Pagueras Portavella]. Barcelona, CATEDRAL, 20.07.1748. E-BC, LIBRO DE BAUTISMOS, VOL. 23, FOL. 138.}

\begin{abstract}
"Als vint de juriol de mil set cents quaranta y vuit en la Seu de Barcelona per mi Dr. Domingo Carles, Prevere y Domer de dita Iglésia fou batejat, Isidro, Llorens, Joseph, fill llegítim y natural de Llorens Pagueras, criat, y de Catharina Pagueras y Portavella, cònjuges. Foren padrins, Isidro Català y Vivas, mestra
\end{abstract} "A veinte de julio de mil setecientos cuarenta y
ocho, en la seo [=catedral] de Barcelona, por mi
[el] Doctor Domingo Carles, cura y
hebdomadario [=-semanero (cura "de guardia"
durante la semana)] de dicha iglesia fue
bautizado, Isidro Llorens Joseph, hijo legítimo
y natural de Llorens Pagueras, criado, y de

53 "Este día se pagaron los derechos de mesa". 


\section{JoAn Benavent Peiró}

boter, y Josepa Vinyas, viuda de Mariano Vinyas, habitans en Barcelona".
Catharina Pagueras y Portavella, cónyuges. Fueron padrinos, Isidro Català y Vivas, maestro botero, y Josepha Vinyas, viuda de Mariano Vinyas, residentes en Barcelona".

IV. Bautismo de Cayeteano Eudaldo Gerónimo [Pagueras portavella]. BARCELONA, CATEDRAL, 31.05.1751. E-BC, LiBRO DE BAUTISMOS, VOL. 24, FOL. 103.

"Als trenta y un de maig de mil set cents sinquanta y un, per mi lo Dr. Joseph Thomás Prevere y Domer de la present Iglésia fonch batejat, Caietano, Eudalt, Gerònim, fill llegítim y natural de Llorens Pagueras, treballador, y de Catharina Pagueras y Portabella, cònjuges. Foren padrins, Caietano Llaró Seller, y Gertrudis Llorens, muller de Eudalt Llorens, tintorer de seda, tots habitants en Barcelona".
"A treinta y uno de mayo de mil setecientos cincuenta y uno, por mí, el doctor Joseph Thomás cura y hebdomadario de la presente iglesia fue bautizado, Cayetano Eudalt Gerónimo, hijo legítimo y natural de Llorens Pagueras, trabajador, y de Catharina Pagueras y Portabella, cónyuges. Fueron padrinos, Cayetano Llaró Seller, y Gertrudis Llorens, mujer de Eudalt Llorens, tintorero de seda, todos habitantes en Barcelona".

V. Demanda matrimonial entre Cayetano Pagueras y Raimunda Cervera al obispado DE BARCELONA, 28.01.1775. E-BC, LlicÈnCIES D'ESPOSALLES, VOL. 151. FOL. 68R.

“[Centrado:] Die 28 Janer anÿ 1775 [...] [En el margen izquierdo:] Pagueras [Centrado:] Caietano Pagueras Musich fill de Llorens y Catha. Portabella conjs. ab Raymunda Cervera dita filla de Jph y Eulalia conjs. Parr[oquia] del Pi... $£ 8 \phi "$.
“[Centrado:] Día 28 de enero [del] año 1775 [...] [En el margen izquierdo:] Pagueras [Centrado:] Cayetano Pagueras, músico, hijo de Llorens y Catharina Portabella, cónyuges, con Raymunda Cervera, dicha hija de Joseph y Eulalia cónyuges [de la] parroquia [de Santa María] del Pino... $f$ $8 \phi "$.

VI. Demanda matrimonial entre lorenzo Pagueras y ignacia Ojeda al obispado de BARCELONA, 26.03.1779. E-BC, LLICÈNCIES D'ESPOSALLES, VOL. 153. FOL. 130R.

“[Centrado:] Die 26 Mars 1779. [...] [En el “[Centrado:] Día 26 de marzo [de] 1779. [...] [En margen izquierdo:] Pagueras [Centrado:] el margen izquierdo:] Pagueras [Centrado:] 
Nuevos datos biográficos de Cayetano y Bruno Pagueras. DE BARCELONA A LA HABANA Y A LA SEU D'URGELL, RESPECTIVAMENTE

Llorens Pagueras xocolater fill de Llorens i / Cath $\underline{\underline{a}}$ Conj ${ }^{\underline{s}}=$ ab Ignasia Ogueda [Ojeda] dita filla de Jph i Jpha conjs Parr[oqui] a Sta Maria... £ $8 \phi ”$.
Llorens Pagueras, chocolatero hijo de Llorens y Catharina, cónyuges, con Ignasia Ojeda, dicha hija de J[ose]ph y J[ose]pha, cónyuges, [de la] parroquia de Santa María... $£ 8 \phi "$.

VII. Carta del Cabildo de la catedral de la Seu D’URgell a Bruno Pagueras COMUNICÁNDOLE EL NOMBRAMIENTO DE MAESTRO DE CAPILLA DE LA CATEDRAL Y LA FECHA DE INICIO DEL CARGO. LA SEU D’URGELL, 10.03.1781 ${ }^{54}$. E-SU, MN. 967. LLIBRE DE CORRESPONDĖNCLA DE 1772 A 1785.

[Margen izquierdo:] [...] "Bruno Pagueras M. de Capilla. [Centrado:] Muy $\mathrm{S}^{\mathrm{r}}$ mio, oy dia de la fecha ha nombrado nuestro cabildo para Maestro de Capilla de esta Cathedral de Urgel a vm. concediendole el salario que a su antecesor $\mathrm{D}^{\mathrm{n}}$ Jayme Balius, y con los mismos cargos de enseñar los mismos infantes de coro, y tañer el organo en ausencias y enfermedades del organista; $y$ en atencion a que la semana $\mathrm{s}^{\text {ta }}$ no está muy lejos; y que para entonces es necesaria la Asistencia del Maestro de Capilla en nuestra Iga Cathedral, esperamos que estará vm. estas fechas de la semana de Pasion lo mas largo y quedando a su disposicon de vm rogamos a Dios le gde m. a. de esta Nuestra Sala capitular de Urgel a 10 de marzo de 1781 [...]".
[Margen izquierdo:] [...] "Bruno Pagueras Maestro de Capilla. [Centrado:] Muy señor mío, hoy, día de la fecha, ha nombrado nuestro cabildo para Maestro de Capilla de esta Catedral de Urgel a vuestra merced, concediéndole el salario que a su antecesor, $\mathrm{D}^{\text {on }}$ Jaime Balius, y con los mismos cargos de enseñar [a] los mismos infantes de coro, y tañer el órgano en ausencias y enfermedades del organista; y en atención a que la semana santa no está muy lejos; y que para entonces es necesaria la asistencia del maestro de capilla en nuestra iglesia catedral, esperamos que estará vuestra merced estas fechas de la semana de Pasión lo más largo, y quedando a su disposición de vuestra merced rogamos a Dios le guarde muchos días de esta nuestra sala capitular de Urgel, a 10 de marzo de 1781 [...]".

VIII. Proclamación a las ÓRDEnes menores de Bruno Pagueras PortaVella en BARCELONA Y EN VILANOVA I LA GELTRÚ ${ }^{55}$. BARCELONA, 07.09.1782. E-SU, ÓRDENES 1780-1782. CAJA 863.

[fol. 1r.:] "A V. S. Y. el Ylmo. Sor. D n. Juan de [fol. 1r.:] [Anotación actual en el margen Garcia / y Montenegro por la gracia de Dios, y superior derecho “1782":] “A Vuestra Señoría de la S ${ }^{\text {ta. Sede / Ap }}{ }^{\text {ca. }}$ Obispo y Señor de Urgel Ilustrísima, el Ilustrísimo Señor Don Juan de

\footnotetext{
${ }^{54}$ La carta fue publicada en los vaciados documentales de los libros de cuenta de la catedral de Urgel para contextualizar la figura del compositor, pero se incluye de nuevo para cotejar los datos aportados (Benavent, 2018).

55 Agradezco al citado canónigo de la catedral de Urgel y archivero del obispado don Benigne Marquès y Sala, la noticia de la existencia de los dos documentos relativos a la proclamación a las órdenes sacerdotales de Bruno Pagueras.
} 


\section{JoAn Benavent Peiró}

Principe Soberano de los / Valles de Andorra del Cons ${ }^{\circ}$. de S. Madd. salud en / Nrõ. Sor. Jesuch ${ }^{\circ}$.

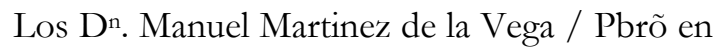
S. Cans. Dor. Ynq ${ }^{\text {or. Ordino }}{ }^{\circ}$. Provisor / y Vic ${ }^{\circ}$. Gen'. por el Ylmo. Sor. Dn. Gavino de / Valladanes [¿Valldares?] y Mesia por la gracia de Dios / y de la Sta. Sede Apca. Obispo de Barna. del / Cons ${ }^{\circ}$. de S. Magd Real

Hacemos saber qe. haviendosenos presentado / por parte de Bruno Pagueras Clerigo Tonsurado / una requisitoria de V. S. Y. para su debido cum, / plimiento mandamos â los R R curas Parro- / cos de Sta. Maria del Mar de esta Ciud. y / de Villanueva de Geltru de este obispado, $\mathrm{q}^{\mathrm{e}}$. en / un dia de la missa maior publicassen y notificas, / sen al Pueblo qe. Bruno Pagueras Clerigo Ton- / surado natural de esta Ciudd. el qual por algun / tiempo havia habitado en dhã Parra . de Villanue, / va deseara ser promovido â los quatro ordens / [fol. 1v.:] menores â fin de $q^{\mathrm{e}}$. si alguna Persona le / supiere algun impedim ${ }^{\text {to }}$. le denunciasen decoro / segundo dia, y de lo que resultasse de dicha / publicacion nos diesen testim ${ }^{\circ}$. en escrito como / y del tiempo $q^{\text {e }}$. huviese sido su repe. feligres; / Y los referidos Curas con el suio de dos / y tres de los corrientes nos han certificado / haver hecho la publicacion, como se les pre- / venia, y mandaba y al tenor del edicto ex- / pedido de nrã Curia, y qe. de ella no havia / resultado impedimento alguno $q^{\mathrm{e}}$. pueda emba- / razar al Pretendiente el ser promovido â los / quatro ordenes menores, si q . constara haver / sido su feligres por mucho tiempo; Otro si de la / informacion de Tesigs. [ं'Testigos?] de orden, y comissión / nrã recibidos consta no tener Bruno Pagueras / embarazo $\mathrm{p}^{\mathrm{a}}$. ser promovido â los quatro ordenes / menores; de todo lo qe. certificamos â V. S. Y. con / las presentes $\mathrm{q}^{\mathrm{e}}$. mandamos expedir firmadas de / nrã mano, selladas con el sello de S. Yll ${ }^{\mathrm{ma}}$. y referendadas / por el infro. Ec ${ }^{\text {no }}$. Bar ${ }^{\text {na }}$. â los siete de sep ${ }^{\text {bre }}$. / de 1782.
García y Montenegro, por la gracia de Dios, y de la Santa Sede Apostólica; Obispo y Señor de Urgel, Príncipe Soberano de los Valles de Andorra, del Consejo de Su Majestad, Salud en Nuestro Señor Jesucristo.

Los Don Manuel Martínez de la Vega presbítero en Santos Cánones Doctor Inquisidor; Provisor y Vicario General por el Ilustrísimo Señor Don Gavino de Valldares y Mesía por la gracia de Dios de la Santa Sede Apostólica, Obispo de Barcelona del Consejo de Su Majestad Real.

Hacemos saber, que habiéndosenos presentado por parte de Bruno Pagueras, clérigo tonsurado, una requisitoria de Vuestra Señoría Ilustrísima para su debido cumplimiento, mandamos a los reverendos curas párrocos de Santa María del Mar de esta ciudad y de Villanueva de Geltrú, de este obispado, que en un día de la misa mayor [es decir, de fiesta de precepto] publicasen y notificasen al pueblo [durante el ofertorio de dicha misa mayor] que Bruno Pagueras, clérigo tonsurado natural de esta ciudad, el cual por algún tiempo había habitado en dicha parroquia de Villanueva, deseara ser promovido a los cuatro órdenes [fol. 1v.:] menores a fin de que si alguna persona le supiere algún impedimento, le denunciasen decoro [el] segundo día, y de lo que resultase de dicha publicación, nos diesen testimonio en escrito, cómo y del tiempo que hubiese sido su representante feligrés, y los referidos curas, con el suyo de dos y tres de los corrientes, nos han certificado haber hecho la publicación, como se les prevenía, y mandaba, $y$ al tenor del edicto expedido de nuestra curia, y que de mano había resultado impedimento alguno que pueda embarazar al pretendiente el ser promovido a los cuatro órdenes menores, sí que constara haber sido su feligrés por mucho tiempo; otrosí de la información de testigos de orden, y comisión nuestra recibidos, consta no tener Bruno Pagueras embarazo para ser promovido a los cuatro órdenes menores; de todo lo que certificamos a Vuestra Señoría Ilustrísima con las presentes, que mandamos expedir firmadas de nuestra mano, selladas con el sello de Su Ilustrísima, y refrendadas por el 
Nuevos datos biográficos de Cayetano y Bruno Pagueras.

DE BARCELONA A LA HABANA Y A LA SEU D'URGELL, RESPECTIVAMENTE

De Vega [Rubrica] / Por mand ${ }^{\circ}$. de S. Gia. / infrascrito escribano. Barcelona, a los siete de Jacinto Barnés Pbrõ Ec no [Rubrica] [Sello en septiembre de 1782. seco del cabildo de Urgel]"

De Vega [rúbrica] Por mandato de Su Gracia Jacinto Barnés, presbítero ecónomo [Sello en seco del cabildo de Urgel]".

\author{
IX. Proclama de las cuatro órdenes menores de Bruno Pagueras Portavella \\ en la Seu d’Urgell. La Seu d’URgell, 26.08.1782. E-SU, Órdenes 1780-1782. Caja \\ 863.
}

[Fol. 1r. impreso:] NOS DON JUAN DE GARZIA, Y MON- / tenegro, per la Gracia de Deu, y de la Santa Sede Apostolica, / Bisbe de Urgéll, Princep Soberá de las Valls de Andora, del Consell / de sa Magestát, \&c.

A vosaltres los Reverents Parroco, eo vostre lloch tinent del [manuscrito:] a Parroquial de San / Dot de la pressent ciutat de Urgell / [impreso:] de Nostre Bisbàt, / y à qui feu de Vosaltres à soles, salut en lo Senyor ab tenor de las presents vos dient, y en virtút de / Poble en vostra Iglesia estarà convocada, y congregada per ohir la Missa Major, y mentras se ce- / lebrarà aquella, à la hora del Ofertori, ab alta, é intellegible veu, publiquéu, y notifiquéu, aixi com / Nosaltres ab tenor de las presents publicam à totas, y qualsevols Personas, de qualsevol estament, / grau, ó condició, que sien, com [manuscrito:] de Bruno Pagueras tonsurat y Mestre de Ca- / pella de aquesta nrã Stã Yglesia Catedral, en las proximas tem- / poras de Setembre ab titol de Patrimoni congruo [impreso:] desitja promoures [manuscrito:] als quatre Menors ordes / [impreso:] Per tant, si ha algú, que sapia, que li dit [manuscrito:] Bruno Pagueras tonsurat [impreso:] no sie fill llegitim, y natural, nat, y procreát de llegitim Matrimoni, y home virtuòs, de vida exem- / plar, fama, y bons costums, y que no frequente los Sagraments de la Penitencia, y Sagrada Comunió
[Fol. 1r. impreso:] "Nos Don Juan García, y Montenegro, por la Gracia de Dios, y de la Santa Sede Apostólica, Obispo de Urgel, Príncipe Soberano de los Valles de Andorra, del Consejo de su Majestad, etc.

A vosotros, los reverendos párrocos, y este vuestro lugarteniente [refiriéndose al párroco de la iglesia, y a su coadjutor o ayudante] de [manuscrito:] la parroquial de San Odón de la presente ciudad de Urgel [impreso:] de Nuestro Obispado, y a quien hizo de vosotros, a solas, salud en el Señor, al tenor de los presentes, os digo: [que] en virtud del pueblo que estará convocado y congregado en vuestra iglesia para oír la Misa mayor, y mientras se celebre aquella, a la hora del Ofertorio, con voz alta e inteligible, publiquéis, y notifiquéis, así como Nosotros, al tenor de las presentes, publiquemos para todas, y a cualquier persona, de cualquier estamento, grado, o condición, que sean, cómo [manuscrito:] Bruno Pagueras, tonsurado y maestro de capilla de esta nuestra Santa Iglesia Catedral, en las próximas témporas de septiembre, con título de patrimonio congruo, [impreso:] desea promoverse [manuscrito:] a las cuatro órdenes menores, [impreso:] Por tanto, si hay alguien, que sepa, que el dicho [manuscrito:] Bruno Pagueras, tonsurado [impreso:] no sea hijo legítimo, y natural, nacido y procreado de legítimo matrimonio, y hombre virtuoso, de vida ejemplar, fama, y buenas 


\section{JoAN BENAVENT PEIRó}

Item, Si saben, ó han ohit dir, que sie excomunicát, suspès, ò entredit, irregular, infame, jugadòr, / usurer, simoniaco, homicida, y si viu amancebàt, ó tè comunicaciò escandalosa ab Donas, ó si es / estat càsat, y en cas ho sia estat, declaren, si una, ó dos vegades, ab Donzella, ó Viuda, y que / temps ha enviudà, si es estàt endemoniat.

Item, Si saben, ó han ohit dir, si te, o se suspita tenir mal caduch, dit vulgarment mal de Sant / Pau, [=epilsepsia] y si es estat, ó impedit de alguna part del cos, que li impedisca lo Exercici dels Sagrats / Ordes, ò pateix altre defecte corporal notable, y deforme, ó just impediment, per lo qual no dega / esser promogùt à dit Sagràt Orde, en continent vos ho hajen de denunciar; y de lo que sabreu, ó / haureu entès, informantvos tambè, per major certesa, ab personas dignas de fer, y timoratas, singu- / larment ab duas de ellas, prenentlas de jurament en vostre poder prestador, que en virtut de ella / digan lo que sapian sobre las cosas preditas, y llurs testificacions autenticas nos las remetréu; y / nos ne informaréu també separadament de tot lo dalt dit; y ademés de això nos ne farèu relaciò / ab vostre sentir, si será, ò no de convenicencia per lo Estat Ecclesiastich, ab vostras Lletras firma- / das, closas, y selladas en forma de Carta; y per esser esta materia tan grave, vos ne encarregàm la / conciencia, y aixi mateix á tots, $\mathrm{y}$ à quiscun dels Faels [¿fieles?], que tindràn noticia de las cosas sobre / ditas, y no las revelarán. Dades en Nostre Palacio Epsicopal de nostra Ciutat de Urgell als [manuscrito:] vint / y sis [impreso:] del mes de [manuscrito:] Agost [impreso:] de mil set cents vuytanta [manuscrito:] y dos. / Juan obpõ de Urgel [rubrica] / [impreso:] De manament de dit Illustrissim Senyor Bisbe de Urgéll, [manuscrito:] Liz ${ }^{\mathrm{t}} \mathrm{D}^{\mathrm{n}}$. Josef Diaz de Basanta [rubrica] [sello en seco del obispado de Urgel].

[fol. 1v. manuscrito:] "Certifico ÿ fas fe jo Joan Cerqueda, ÿ Mas Pbre Beneficiat y Curat de la Par- / roquia de San Od [san Odón] de la Yga Cath1. de Urgell Com lo dia vint y vuit del mes de / Agost dels anÿs mil set cens vuÿtanta y dos que era lo dia de San Agusti / he Publicat en la costumbres, y que no frecuente los sacramentos de la Penitencia, y Sagrada Comunión,

Item, si saben, o han oído decir, que está excomulgado, suspendido, o entredicho, irregular, infame, jugador, usurero, simoníaco, homicida, y si vive amancebado, o tiene comunicación escandalosa con mujeres, o si ha estado casado, y en el caso de que lo haya estado, declaren, si una, o dos veces, con doncella, o viuda, y cuando enviudó, si ha estado endemoniado,

Item, si saben, o han oído decir, si tiene, o se sospecha que tiene un mal caduco, dicho vulgarmente mal de San Pablo [=epilepsia], y si está o ha estado impedido de alguna parte del cuerpo, que le impida el ejercicio de las órdenes sagradas, o padece otro defecto corporal notable, y deforme, o justo impedimento, por el cual no deba ser promovido a dicha orden sagrada, en conjunto os lo tengan que denunciar; y de lo que sepáis o hayáis entendido, informándoos también, para mayor certeza, con personas dignas de crédito, y timoratas, singularmente con dos de ellas, tomándoles juramento en vuestro poder prestador, que, en virtud de ella, digan lo que sepan sobre las cosas predichas, y sus testificaciones auténticas nos las remitiréis; y nos informaréis también separadamente de todo lo dicho arriba; y además de esto, nos haréis relación con vuestro sentir; si será, o no, de conveniencia para el estado eclesiástico, con vuestras letras firmadas, cerradas, y selladas en forma de carta; y por ser esta materia tan grave, os encargamos la conciencia; y así mismo a todos, y a cada uno de los faels [sic] [¿fieles?] que tengan noticia de las cosas antedichas, y no las revelarán. Hechas en Nuestro Palacio Episcopal de nuestra Ciudad de Urgel, a los [manuscrito:] veinte y seis [impreso:] del mes de [manuscrito:] Agosto [impreso:] de mil setecientos ochenta [manuscrito:] y dos. Juan, Obispo de Urgel [rúbrica]. [Impreso:] De mandato de dicho Ilustrísimo Señor Obispo de Urgel, [manuscrito:] Licenciado Don Josef Díaz de Basanta [rúbrica] [sello en seco del obispado de Urgel]. 
Nuevos datos biográficos de Cayetano y BRUno Pagueras.

DE BARCELONA A LA HABANA Y A LA SEU D'URGELL, RESPECTIVAMENTE

Parroquia de San Od D. Bruno Pagueras Mestre de / Capella de la Yga. Cathedral de Urgell per a ser promogut als quatre / ordres menors y no he trobat, ni se me ha opposat, ni se que tinga impe- / diment Canonich algun perque dit Bruno Pagueras no sia promo- / gut a dits quatre ordes y per a est fi ha pres a dos testimonis com / son lo Rt Joseph Gali y lo $\mathrm{S}^{\mathrm{r}}$ Llorens Llurba los quals han jurat no / sabian que dit Bruno Pagueras tinges ningun impediment antes / be que lo tenien per convenien al estat Eclesiastich; Y per a que conste / fas lo precent certificacio jo lo mateix Joan Cerqueda y Curat ex- / presat vuy dia trenta de Agost de mil set cens vuytanta ÿ dos y ho / firmo y Signo ab mon acostumat signe [rúbrica notarial]

En testimoni de veritat Joan Cerqueda Curat [rubrica]". [fol. 1v. manuscrito:] Certifico y doy fe, yo, Joan Cerqueda y Mas, presbítero beneficiado y cura de la Parroquia de San Odón de la Iglesia Catedral de Urgel como el día veinte y ocho del mes de Agosto del año mil setecientos ochenta y dos, que era el día de San Agustín, he publicado en la Parroquia de San Odón [a] Don Bruno Pagueras, Maestro de Capilla de la Iglesia Catedral de Urgel para ser promovido a las cuatro órdenes menores y no he encontrado, ni se me ha opuesto, ni sé que tenga impedimento canónico alguno, para que dicho Bruno Pagueras no sea promovido a dichas cuatro órdenes, y para dicho fin ha tomado a dos testigos como son el reverendo Joseph Galí y el señor Llorens Llurba, los cuales han jurado no saber que dicho Bruno Pagueras tuviese impedimento alguno antes bien que lo tenían por conveniente al estado eclesiástico; y para que conste, hago el presente certificado, yo, el mismo Joan Cerqueda, y curado [es decir, cura responsable de la parroquia] expresado hoy, día treinta de agosto de mil setecientos ochenta y dos, y lo firmo y rubrico con mi firma acostumbrada [rúbrica notarial].

En testimonio de verdad, Joan Cerqueda, curado [rúbrica]".

\section{Testamento de Bruno Pagueras Portavella ante el juez de la Seu D’Urgell JoAn Juer Albertí, 03.06.1836. E-BAC, NotAriales, VÀria, Lligall No 836, 130R. - 130v.}

[fol. 130r.] [Sello en tinta y en seco:] Sello $4^{\circ} 40$ mvs. [maravedís] Año de 1836. Dia 3 Juny 1836. / En nom de Nostre Sor Deu Jesuchrist sia, Jo lo Rnt Bruno / Peguera Pbre Mestre de capella jubilat de esta Santa Yglesia de Urgell, / vehi de la mateixa, fill llegitim y natural de Llorens y Catarina Pe- / guera y Portavella conj ${ }^{\text {s. }}$ difunts de la ciutat de Barnã, estant detin- / gut en lo llit de una grave malaltia corporal de la cual temo mo- / rir; pero per la gracia de Deu ab claredat de potencias y / sentits y ferma paraula; volent [fol. 130r.] [Sello en tinta y en seco:] "Sello $4^{\circ} 40$ maravedís Año de 1836. Dia 3 junio 1836. En nombre de Nuestro Señor Dios Jesucristo sea, Yo, el reverendo Bruno Peguera, presbítero, maestro de capilla jubilado de esta Santa Iglesia de Urgel, vecino de la misma, hijo legítimo y natural de Llorens y Catarina Peguera y Portavella, cónyuges, difuntos, de la ciudad de Barcelona, estando detenido en la cama de una grave enfermedad corporal, de la cual temo morir; pero por la gracia de Dios, con claridad 


\section{JoAn Benavent Peiró}

disposar de mos bens temporals fas y orde- / no lo present meu testament ultima y postrera voluntat mia / ab la cual anomeno per Masmesors y del present meu testament / Executors als Rnt Jaume Subirás [¿'Subiras / Subías?] y D. Joaquim Orriols Pbres / y Beneficitas de dita Santa Yglesia, als cuals junts y á solas dono / ple poder y facultat de cumplir y executar lo present meu tes- / tament en la forma seguent.

Primerament vull que tots mos deutes, sian pagats y esme- / nadas las injurias á la major brevetat.

Elegesch la sepultura en lo sementiri de la Parroquia Yglesia / de San Od de esta ciutat; volent que lo enterro, honras y numero / de missas se me fassa y celebria en lo modo y numero que / determinen mos Masmesors.

Deixo per una vegada solament dotse reals de velló al Monte- / pio de pobres viudas, cuyos marits han mort en la Guerra / conforme está manat per ordres superiors.

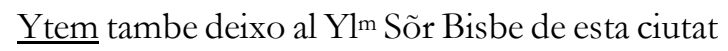
y Bisbat / mon Prelat lo dret de morabatí.

Ytem per los bons serveys tinch rebuts de ma actual Patrona / vull que luego de seguida la mia mort se li entreguin tres / llansols que sian bons y dels tres matalasosos que tinch que se / entregui lo un á la mateixa Patrona mia del cual y dels / dits tres llansols podrá disposar librement.

En tots los altres emperó bens meus, noms, veus drets, for- / sas y accions mias universals mobles é inmobles que vuy / tinch y en avant tindré y me espectarán en cualsevol part y [fol 130 v.] per cualsevol nom ó causa instituhesc hereu meu universal / a Deu nostre señor y á la mia anima; volent que per los so- / bredits mos masmesors sian venuts tots mos bens al publich / subast ó privadament, y de son resultat que sian fetas celebrar / missas resadas a la caritat que millor aparega á dits mas- / mesors celebradoras en las Yglesias, Altars y per los sacerdots / que aquells disposarán per salut y de potencias y sentidos, y firme palabra; queriendo disponer de mis bienes temporales, hago y ordeno el presente mi testamento, última y postrera voluntad mía, con la cual designo por albaceas del presente mi testamento, ejecutores, a los reverendos Jaume Subirás [¿Subiras / Subías?] y don Joaquim Orriols, curas y beneficiados de dicha Santa Iglesia, a los cuales, juntos y a solas doy pleno poder y facultad de cumplir y ejecutar el presente mi testamento en la forma siguiente.

Primeramente, quiero que todas mis deudas, sean pagadas y corregidas las injurias a la mayor brevedad.

Elijo la sepultura en el cementerio de la parroquia iglesia de Sant Odón de esta ciudad; queriendo que el entierro, honras y número de misas, se me hagan y celebren en el modo y número que determinen mis albaceas.

Dejo, por una vez solamente doce reales de vellón al Montepío de pobres viudas, cuyos maridos han muerto en la guerra, conforme está mandado por órdenes superiores.

Ytem, también dejo al Ilustrísimo Señor Obispo de esta ciudad y obispado, mi prelado, el derecho de morabatí.

Ytem, por los buenos servicios [que] tengo recibidos de mi actual patrona, quiero que después en seguida de mi muerte, se le entreguen tres sábanas que sean buenas; y de los tres colchones que tengo, que se le entregue uno a la misma mi patrona, del cual, y de las tres dichas sábanas, podrá disponer libremente.

En todos los otros, y no obstante, mis bienes, nombres, voces diestras, fuerzas y acciones universales muebles e inmuebles que hoy tengo y en adelante tendré, y me vendrán en cualquier parte y [fol. 1v.:] por cualquier nombre o causa, instituyo heredero mío universal a Dios nuestro señor, y a mi alma; queriendo que por los sobredichos mis albaceas, sean vendidos todos mis bienes en pública subasta o privadamente, $\mathrm{y}$ de su resultado, que se hagan celebrar misas rezadas a la caridad que mejor parezca a dichos 
Nuevos datos biográficos de Cayetano y BRUno Pagueras.

De Barcelona a La Habana y A La SEU D'URgEll, RESPECTIVAMENTE

remey de la mia anima / y demes de la mia major obligació, absolventlos de pendrer inventa- / ri, ni donar compte ni rahó á persona alguna per la gran confi- / ansa que de ells tinch.

Revoco ab lo present tots y cualsevols altres testaments, codicils y / demes especies de ultima voluntat per mi fins al present fets / y fetas especialment lo que tinch otorgat en poder del Not[ari] infr[raescr]it / á quinse de Abril de mil vuit cents trenta cuatre; volent / que la present mia testamentaria disposició, prevalga a las demes: / Que seguit mon obit sia publicada, y despues donades las copias au- / tenticas que donadas seran per las Parts interesants.

Aquesta es la mia ultima voluntat que vull valga per dret de / testament codich ó de aquella altra especie de ultima voluntat / que millor de dret, valer y tenia podrá.

Fet fou lo present meu testament en la ciutat de Urgell als / tres dias del mes de juny del any mil vuit cents trenta sis; / essent presents per testimonis cridats y pregats Joseph Mir Escribent y Anton Deltor y Prats negociant los dos vehins de / esta ciutat, Y lo Rnt testador á qui jo lo Not[ari] infr[raescr]it fas fe / que conech, no ho firma per la sua edat tant avansada, cor- / tedat de sa vista y tremolarli lo pols y de sa voluntat y con- / sentiment firma per ell lo infr[aescr]it testimoni.

Per lo Rnt testador, Joseph Mir.

En poder de mi

Joan Juér y Albertí [rubricado]”. albaceas, celebrándose en las iglesias y altares, y por los sacerdotes que aquellos [se refiere a sus albaceas] dispongan, para salud y remedio de mi alma, y demás de mi mayor obligación, absolviéndolos de hacer inventario, ni de dar cuenta ni razón a persona alguna, por la gran confianza que en ellos tengo.

Revoco con el presente todos y cualesquiera otros testamentos, codicilios y otras especies de últimas voluntades, hechas por mí hasta el presente, y realizadas especialmente. Lo que tengo otorgado en poder del notario infrascrito, a quince de abril de mil ochocientos treinta y cuatro; queriendo que la presente mi testamentaria disposición, prevalga ante el resto. Que después de mi óbito se publique, y después, dadas las copias auténticas que entreguen las partes interesadas.

Esta es mi última voluntad, que quiero sirva como derecho de testamento, codicilio o aquella otra especie de última voluntad que mejor tenga poder de derecho y valor.

Hecho fue el presente mi testamento en la ciudad de Urgel, a los tres días del mes de junio del año mil ochocientos treinta y seis; estando presentes, por testigos, llamados y convocados, Joseph Mir, escribiente y Anton Deltor y Prats, negociante; los dos, vecinos de esta ciudad, y el reverendo testador, a quién yo, el notario infrascrito, doy fe que conozco; no lo firma por su edad tan avanzada, cortedad de vista, y por temblarle el pulso; y de su voluntad y consentimiento, firma por él el infraescrito testigo.

Por el reverendo testador, Joseph Mir.

En poder de mí,

Joan Juér y Albertí [rubricado]”.

Fecha de recepción: 04/11/2020

Fecha de aceptación: 23/06/2021 